\title{
Opening a Door for Return to Home: Impact and Effectiveness of Turkish Repentance Laws
}

\section{Mustafa Cosar Unal}

To cite this article: Mustafa Cosar Unal (2016) Opening a Door for Return to Home: Impact and Effectiveness of Turkish Repentance Laws, Studies in Conflict \& Terrorism, 39:2, 128-164, DOI: 10.1080/1057610X.2015.1093889

To link to this article: https://doi.org/10.1080/1057610X.2015.1093889

册 Published online: 29 Oct 2015.

Submit your article to this journal $\pi$

III Article views: 317

Q View related articles $₫$

View Crossmark data $\nearrow$

Citing articles: 2 View citing articles 


\title{
Opening a Door for Return to Home: Impact and Effectiveness of Turkish Repentance Laws
}

\author{
Mustafa Cosar Unal \\ Department of Political Science and Public Administration, Bilkent University, Ankara, Turkey
}

\begin{abstract}
This study analyzes the impact of the Turkish Repentance Laws in undermining the Kurdistan Workers Party (PKK). Did the repentance laws increase the PKK surrender, thereby decreasing the PKK violence? Vector Auto-Regression analysis indicates that enactment of repentance laws did not have any significant impact on PKK surrenders, failing to significantly decrease PKK violence. Yet it does not establish any meaningful relationship between the use of force and PKK surrenders. Descriptive analyses show the significant number of surrenders took place in 1993-94, 2001, and 2003, while the highest number of penitents submitted to the "Return to Home Law" in 2003. These values relate to a specific context. This study, however, asserts that surrendered and applicant PKK members were too few to influence the overall conflict, concluding that, in addition to what these laws mean to the penitents, the success/failure of repentance policies are related to the nature of Turkey's counterinsurgency and their respective context.
\end{abstract}

\section{ARTICLE HISTORY}

Received 20 July 2015

Accepted 7 September 2015

\section{Introduction}

Kurdish dissent is a deep-rooted historical issue in Turkey. The ideological infrastructure of the Kurdish uprising dates back to the Ottoman Empire. In that, Kurdish unrest is an ethnonational identity conflict that re-emerged in both internal and external contextual dynamics in the 1970s. ${ }^{1}$ Not only did it coincide with the third wave of modern terrorism as classified by David Rapoport, which is the "new left wave" of the $1970 \mathrm{~s},{ }^{2}$ but also with the new cycle of national awareness that was universally induced by the nation-state phenomenon of the Cold War and post-Cold War era.

Turkey was involved in a prolonged struggle against the Kurdish insurrection led by the Kurdistan Workers' Party (PKK). The PKK conflict, emerging in 1973 and officially starting in 1984, caused more than 40,000 deaths by 2013 , when Turkey engaged in a resolution process along with a cease-fire. Between 1984 and 2013, a total of 14,755 non-combatants (civilians, government staff [e.g., teachers, imams]) were either killed or injured as a result of the conflict. For security forces this figure reaches as many as 16,249 killed or injured persons. The fatality rate for civilians has reached only 5,478; while it is 6,764 for the state security

CONTACT Mustafa Cosar Unal cosar.unal@bilkent.edu.tr Bilkent University, Department of Political Science and Public Administration, 06800 Bilkent, Ankara, Turkey 
forces. The PKK killed 124 teachers and 336 government staff members (e.g., imams, certain other workers, and clerks).

In its response to the PKK, Turkey employed various counterterrorism policies, which reflect a wide variety of approaches indicating an evolution from exclusively military-led repressive measures to accommodative democratization policies to address the Kurdish problem. Among these, there are two types of policies that Turkey implemented throughout. The first is the use of military force in a changing role and scale, and the other is repentance law. As plotted in Table 1, a total of 26,781 PKK militants were killed and another 929 were injured as a result of military operations between 1984 and 2013. Second, in the entire period of the conflict, Turkey adopted nine different repentance laws to disrupt and mitigate the Kurdish Insurrection. Similar to the use of military force, implemented repentance opportunities yield a changing nature in their content and application (elaborated later). As Table 1 demonstrates, between 1984 and 2013, a total of 4,811 PKK members surrendered to security forces while 6,679 were captured alive during military operations.

As is known, granting repentance opportunity is one of the countermeasure tools that are commonly used by states. States resort to this policy so individuals, once involved in terrorist and/or insurgent activities, have a chance to leave political violence behind. Granting an open door for penitents to award their return to home and to reintegrate them into the society has multiple aims for states. It can be considered as a form of psychological warfare aimed to encourage insurgents' surrender; second, to trigger a disintegration process through dissention and defection; third, to increase the perceived legitimacy of governments by keeping an open door for pardon and to accommodate once involved in terrorism. ${ }^{3}$ In most cases, however, where there is an ongoing struggle, it also aims at tactical victories by exploiting surrendered individuals for information acquisition on the whereabouts of their former comrades. 4

Within this context, this article focuses on Turkey's Repentance Laws and, in the first place, it analyzes their impact on PKK violence over time since these policies were implemented to curtail PKK insurgency. Second, it identifies any meaningful relationship between implemented repentance laws and surrendered PKK militants; in other words, it addresses if granting repentance opportunities (award measure) had a correlative impact on surrenders by PKK militants. Third, it addresses whether or not incapacitating PKK's armed militants was a significant factor in their surrender as a part of the logic of increasing material or the opportunity cost of terrorism from a rational choice perspective. Special focus is devoted to the overall success of repentance laws in their impact to reduce or limit the Kurdish insurgency.

Based on the aforementioned goals, this article is divided in three main parts. The first briefly introduces the implementation and content of the Turkey's Repentance Laws. In the second part, after discussing the methods, the conceptual and empirical models and other necessary details about the data and variables, it actually runs the quantitative analyses by using Vector auto-regression technique and portrays the results. In the third and final

Table 1. Number of killed injured, captured, and surrendered PKK members, 1984-2013.

\begin{tabular}{llll}
\hline & \multicolumn{2}{c}{ Incapacitated PKK militants } \\
\hline PKK members & Killed 26,781 & Injured 929 & Casualty 27,710 \\
PKK members & Surrendered/capitulated 4,811 & Captured (alive) 6,679 & Totalnumbers 39,200 \\
\hline
\end{tabular}


section, to relate the findings from the quantitative analyses, it respectively elaborates the underpinnings of granting repentance opportunity from the perspective of individual and collective disintegration; next, it discusses repentance policy illustrating different cases from Italy, Peru, Spain, England, and Colombia; it provides a descriptive analysis of the PKK case in which the trend of surrender, level of violence and trend of incapacitation (use of force) and capture are discussed along with all implemented Turkish repentance laws during the entire duration of the PKK conflict; it finally analyzes the characteristics of Turkish repentance laws with their changing nature and content (i.e., stipulations, conditions, the social identity offered by different laws and etc.).

\section{Turkish Repentance Laws}

Repentance laws create a window of opportunity for terrorists to abandon their terrorist activities and to become reintegrated into the societal fabric. These laws were intended, however, mostly for the PKK militants, given the scale of PKK threat to Turkey's national security. The actual goal was to initiate a mass disintegration process via individual disintegration among the members of the PKK by allowing the militants, who found themselves regretful about their hostile activities, to surrender to security forces. In so doing, the end goal for the state is to weaken, reduce and, finally, dismantle the PKK-led insurgency.

These laws inducing repentance opportunities have certain characteristics that can be categorized into three chronological sets. The first set, covering the initial seven repentance laws, is known as general repentance laws (RLs), which did not have specific names. The second set is the "Reinstatement into Society Law" or the "Return Home Bill" (RHB) of 2003; the third set is comprised of the "Effective Repentance Law of 2005" (ERL), which is still in effect. Despite slight differences, the first two sets including seven RLs and the RHB-out of nine-were fundamentally analogous requiring certain conditions for an applicant to benefit from the law, while the ERL came out with certain specific and important differences in its content.

The first two sets (RLs and RHB) of laws were comprised of three essential components similar to many other examples (e.g., the Italian pentimento), which sought practical results through full confession and collaboration to avert future violence as the basic condition of the law in order to benefit from it. These include: first, repentance laws granted amnesty for terrorists ${ }^{5}$ who have never engaged in any kind of violent attack resulting in human fatalities and injuries. Eligible PKK members could qualify for repentance with no sentencing and with supplementary services of witness protection opportunities. For those who have been involved in other nonviolent activities such as providing material (e.g., any kind of logistical support) and psychological support (e.g., propaganda) to the terrorist organization could also benefit from the law.

Second, repentance laws granted a reduction of the punishment for terrorists who had been involved in high profile violent attacks resulting in fatalities and injuries, if the terrorist surrendered to security forces and agreed to cooperate with security forces. This cooperation includes providing information and intelligence related to terrorists' resource endowments, strongholds of PKK fighters, future attacks, and strategic plans. The reduction of punishment would be one-fourth of the original penalty specified by the Turkish Penal Code. Courts are authorized to decide whether the information provided by the applicant is satisfactory to qualify for the amnesty. 
Third, repentance laws, except for the ERL, declared terrorist members holding managerial positions within the organization are ineligible to benefit from the law. The main logic behind this was to underline the fact that even though the incumbents of upper cadres do not personally become involved in violent attacks, they plan and coordinate such attacks. The ERL included leaders, however, by stipulating their capitulation along with the group under their command. Finally, to prevent possible discouragements for the PKK members to capitulate, repentance laws granted protection to terrorists who decided to surrender under the terms of the repentance laws against possible threats from the terrorist organization. As opposed to the former eight laws, the ERL did not include protection for the repented, but this law is accompanied by another specific law designed to protect state witnesses (i.e., 5,726 Witness Protection Law implemented on 27 December 2007).

As summarized in Table 2, the ERL, in contrast to its counterparts, included significant differences as well as some analogies. These differences are in terms of both their material and psychological underpinnings and meanings for the state and the repentant, which are elaborated later in the discussion section.

\section{Methods}

This section introduces the conceptual model, discusses the nature and characteristics of the data and provides the list of used variables along with their operational definitions. It later introduces the Vector Auto-Regression (VAR) as the analysis technique to address the quantitative part of this research. Next, it develops the empirical model on which the specific VAR model for this study is constructed. Then, it briefly discusses the procedures of VAR analysis and, finally, presents the VAR results.

\section{Conceptual Model}

The focus of this study is to identify whether the enactment of repentance opportunities resulted in PKK fighters' surrender/disengagement from the PKK and thus led to any decrease in the PKK-initiated violence. It also analyzes whether or not incapacitating (killing and injuring) insurgents through intense military operations resulted in their surrender. Therefore, the main interest of this study is to empirically address four main research questions. First, it analyzes the impact of Turkish RLs on the PKK members' surrender to identify whether or not the PKK fighters perceived the repentance as an effective window of

Table 2. Three sets of repentance laws that have been implemented by the Turkish Government between 1984 and 2015.

\begin{tabular}{lccc}
\hline Title & Come into force & Identity & Implication \\
\hline Repentance laws & $11 / 06 / 1985$ & "Repentant" "Confessor" & Disintegration from the PKK \\
& $30 / 03 / 1988$ & "Informant" & Full force of physical and \\
$27 / 03 / 1990$ & & psychological collaboration. \\
$29 / 11 / 1992$ & & Stay in violence for the state security forces \\
$08 / 03 / 1995$ & & \\
$28 / 08 / 1999$ & & \\
& $27 / 02 / 2000$ & & \\
Reinstatement into society & $06 / 08 / 2003$ & & Disintegration from violence \\
Return to Home Bill & $01 / 06 / 2005$ & "State Witness" & \\
Effective repentance law & $01 / 06 / 20$
\end{tabular}


opportunity to turn back from their terrorist past (i.e., return their home and reinstate into the society). Second, it analyzes how successful these RLs have been in reducing the PKK-initiated violence, given that these laws were implemented to maintain PKK fighters' disengagement from violent activities and thus to mitigate the PKK workforce. Third, it questions if there is any relationship between use of force/incapacitation and surrendered fighters, since military operations aiming at incapacitation of insurgents intend to deter insurgent violence by increasing material cost (i.e., increasing certainty of apprehension and threat of being killed and injured) of engaging in terrorist/insurgent activity. Fourth, it analyzes if there is a meaningful relationship between surrender (as a result of repentance opportunity and/or military pressure) and level of PKK-initiated violence.

The cease-fire periods are also incorporated into the analysis to partition out their effect in order to reach more reliable results. This is because the PKK unilaterally declared nine cease-fires for different reasons in the entire span of the conflict and they actually refrained from attacking (unless they had to attack in the context of "active defense concept" as they named it). ${ }^{6}$ Seven out of these nine cease-fires fall into the period that the data used for this study cover (1995-2010). Another important conceptual issue is the retaliation effect between incapacitation and PKK-initiated attacks, which is also captured in the created VAR model (elaborated in the next section, where the empirical model is constructed). Its impact is isolated from the impact of the policy shift (implementation of the repentance laws in this case). In addition to the VAR analysis, the number of PKK-initiated violent attacks and resulting casualties, surrenders, incapacitations are analyzed to discuss, explain, and supplement the VAR results and to compare these with the results from other cases from different countries.

In short, analyzing the level of surrenders, enactment of RLs, and the level of PKK-initiated violence is considered in order to determine to what extent, or if at all, the Turkish RLs impacted surrender of PKK militants and the PKK-initiated violence. Yet, questioning the relationship between the number of incapacitated PKK militants and that of surrendered helps identify whether or not the intense use of force/incapacitation has significantly impacted the PKK militants' surrendering/capitulating.

\section{Data and Variables}

To address the aforementioned RQs, this study analyzes almost the entire span of the conflict, from 1984, when the PKK officially commenced its fight, until 2013, when violence ceased due to the ongoing resolution process between the State and the PKK. In that, to conduct VAR analyses, the study used official governmental dataset that were extracted from the database of the Turkish National Police, Department of Counterterrorism. This is an incident level longitudinal dataset that includes monthly data/observations between 1995 and 2010. This study also used Department of Intelligence's dataset that only gives aggregate level annual data which covers almost the entire period of the conflict: 1984-2013. The second dataset is mostly used for analyses in the qualitative section, such as annual aggregate levels of violence and casualties, number of killed, injured, and captured PKK militants and so forth. Therefore, the quantitative section with VAR analyses covers the timespan from 1995 to 2010 due to data availability in monthly observations, while the descriptive analyses cover the entire period of 1984-2013 with only annual data points from the official government datasets. 
The population and the sample frame of the datasets include violent incidents coded in the government's official database. Every single violent event related to the PKK is officially reported (through the official chain of units) to the central office in the main headquarters. The dataset includes monthly data covering the period from January 1995 to December 2010. Coded variables used from the government database are: the number of resulting casualties due to the PKK attacks, number of PKK-initiated violent incidents, the number of killed and injured (incapacitated) PKK fighters/militants (used interchangeably), and the number of capitulated/surrendered PKK militants. All variables are restructured into observations based on monthly intervals of time. The variables used in the analyses are listed in Table 3, followed by their operational definitions.

Violent incidents refer to the acts of extreme aggression and physical force that mostly resulted in human casualties, as well as damage and destruction to property.

VIOLENCE refers to the civilian and security force casualties (killed and injured) due to the PKK conflict. Casualties among security forces also include those belonging to the provisional village guards (known as GKKs) in addition to military personnel and police forces. This happens because the GKKs are trained and armed by Turkish Army not only to defend their remote villages/hamlets, but also to help security forces in their military operations in the region.

INCAPTER refers to the number of incapacitated PKK militants, which is measured by the total number of killed and injured PKK fighters.

SURRENDER refers to the number of PKK fighters who left the PKK and capitulated to the Turkish Security Forces (official request for benefitting from the repentance opportunity is a subsequent process).

REPENT refers to the implemented Repentance Laws and it is a dummy shift variable reflecting policy shift; it is coded " 1 ," when the law is active, otherwise it is coded " 0 ."

CEASEFIRE indicates unilateral cease-fire periods declared by the PKK in which ceasefires are coded as dummy variables (permanent level shift) of " 1 " for the period when the cease-fires were in effect and " 0 " for when they were not.

Turkey has implemented a number of repentance opportunities for individuals who engaged in terrorist activities. The main target of these repentance laws, however, has been the PKK fighters to diminish PKK violence and to trigger a disintegration/dissolution process within the PKK.

During the history of the PKK conflict, the Turkish Parliament passed nine different repentance laws in different names, with different time limits and contents (e.g., Repentance Law, Return to Home Bill, Reinstatement into Society Law, Effective Repentance). Each one of the repentance laws except the latest one, entitled "Effective Repentance Law (came into force in 2005)," was featured to be a sunset law that was in effect for a certain length of time. All repentance laws that have been enacted so far are enlisted in Table 4.

Table 3. List of variables from the government dataset for the VAR analyses.

\begin{tabular}{ll}
\hline Variables & \multicolumn{1}{c}{ Explanation } \\
\hline VIOLENCE & Number of killed, injured civilians/security forces due to PKK attacks. \\
INCAPTER & Number of killed and injured (incapacitated) PKK militants. \\
SURRENDER & Number of surrendered PKK militants. \\
REPENT & Implemented Repentance Laws, in effect "1," otherwise "0" \\
CEASEFIRE & Unilateral cease-fires declared by the PKK, in effect "1," otherwise "0" \\
\hline
\end{tabular}




\section{Empirical Model and Analysis Technique}

\section{VAR in General}

As it is known, VAR is used in time series analyses with many different purposes, one of which is the policy analysis. ${ }^{7}$ To address the aforementioned RQs, the author used a VAR technique to longitudinally assess and analyze the impact of repentance laws, which represent one of the policies that Turkey implemented among its countermeasures against the PKK. VAR models focus on the underlying correlation between multiple time series variables to identify the dynamic structure among those variables. To do this, as opposed to other approaches to time series analyses, VAR models do not assume to know the correct structure of the underlying relationships that generated the multiple time series, ${ }^{8}$ since VAR is specifically designed to capture and characterize the uncertainties and structural dynamics among the time series in an unrestricted manner, without precisely knowing the true dynamics and relationships in most cases. ${ }^{9}$ VAR is an n-equation, $n$-variable model in which each variable is explained by its own lagged values, as well as by the lagged values of the remaining (n-1) variables for the endogenous variables and current values of the exogenous variables. ${ }^{10}$ Paraphrased, VAR is a multivariate autoregressive model in which each endogenous variable is regressed on its past values and past values of the other endogenous variables and current values of the exogenous variables in the system to identify the relationship, if any, among longitudinal time series variables. Thus, VAR, as a model to analyze the dynamic impact of random disturbances on the system of variables, does not need structural modeling because it treats every endogenous variable in the system as a function of the lagged values of all of the endogenous variables in the system.

\section{Constructing (Empirical) VAR Models}

This study, as explained earlier, is intended to analyze the impact of Turkish RLs and related surrenders on four different accounts. First, it questions the effectiveness of the Turkish repentance laws (REPENT) in identifying their impact on the PKK members' surrender (SURRENDER). Second, it analyzes if implementation of repentance laws (REPENT) had any impact on the PKK-initiated violence. Third, it identifies whether or not there is a meaningful relationship between surrendered (SURRENDER) PKK fighters and PKK-initiated violence (VIOLENCE). Lastly, it analyzes the relationship, if any, between incapacitation (INCAPTER) and surrendered fighters (SURRENDER) to identify whether or not the use of force through military operations had any profound impact on the PKK militants in

Table 4. Repentance Laws implemented by the Turkish government between 1984 and 2015.

\begin{tabular}{llll}
\hline No. & Came into force & Bill no. & Time limit \\
\hline 1 & $11 / 06 / 1985$ & 3216 & Two years \\
2 & $30 / 03 / 1988$ & 3419 & Two years \\
3 & $27 / 03 / 1990$ & 3618 & One year \\
4 & $29 / 11 / 1992$ & 3853 & Two years \\
5 & $08 / 03 / 1995$ & 4085 & Four months \\
6 & $28 / 08 / 1999$ & 4450 & Six months \\
7 & $27 / 02 / 2000$ & 4537 & Six months \\
8 & $06 / 08 / 2003$ & 4959 & Six months \\
9 & $01 / 06 / 2005$ & 5237 & Onward (Active) \\
\hline
\end{tabular}


dissuading them from being part of the PKK and convincing them to surrender. The author has also incorporated the unilaterally declared cease-fires (CEASEFIRE) to isolate their effects from the results.

Figure 1 visually diagrams the synopsis of the empirical model. As indicated in the figure, this model analyzes the relationships between VIOLENCE, INCAPTER, and SURRENDER. The two-way relationships are denoted with arrows indicating the questioned cause-and-effect/correlation in a pairwise structure between the longitudinal variables. The bold arrows denote what this study addresses in this analysis. In addition to the pairwise analysis regarding whether or not there is a meaningful (causal) relationship between SURRENDER and VIOLENCE, it examines if there is a statistically proven impact of SURRENDER on VIOLENCE. Likewise, it analyzes if incapacitation (INCAPTER) had an impact on the level of surrendered (SURRENDER) PKK fighters. The REPENT is introduced into the system as an exogenous variable to analyze all these relationships when repentance laws are in effect to see if implementation of repentance opportunity (REPENT) had an impact on the level of PKK violence (VIOLENCE). Unilaterally declared cease-fires (CEASEFIRE) are also introduced into the system to incorporate their impact on the examined relationships. The mathematical representation of the model is portrayed in the Appendix.

To address the aforementioned research questions, a reduced ${ }^{11}$ form of VAR Model is constructed. In this model, INCAPTER, VIOLENCE, and SURRENDER (all scale level) are incorporated into the system as endogenous variables to seek the aforementioned relationships while REPENT is introduced as an exogenous variable to see the impact of its intervention. To incorporate the cease-fire terms where PKK refrained from attacking (which is also tested), CEASEFIRE periods are also introduced as an exogenous variable into the VAR system. Walter Enders and Todd Sandler used a similar model, ${ }^{12}$ where they analyzed the substitution effect among different modes of attack in transnational terrorism. In this framework, the effect of terrorist violence and use of force are allowed to affect each other so that the retaliatory effect of use of force can also be identified. Yet, cease-fire periods are also incorporated into the VAR system to isolate time periods where the PKK-for different reasons-refrained from terrorist attacks, which decreased the PKK-initiated violence. $^{13}$

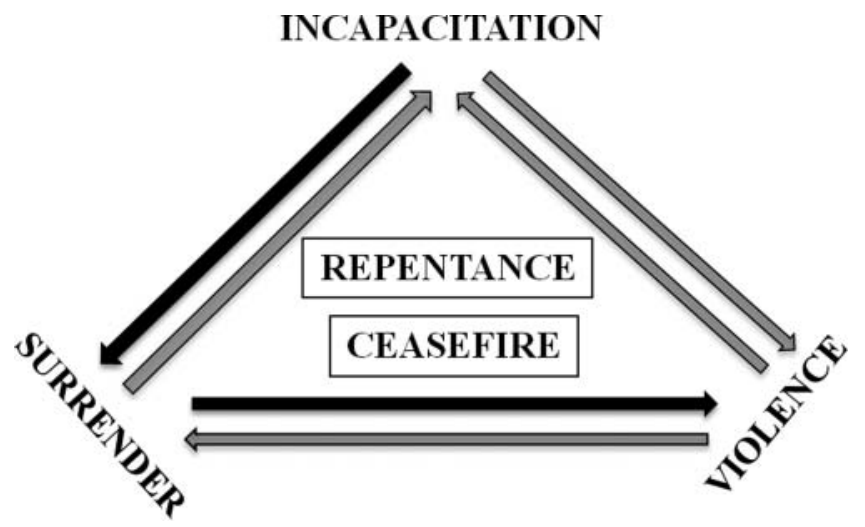

Figure 1. Visual diagram of the empirical model's synopsis. 


\section{Procedure of VAR Analysis}

The VAR analysis needs to meet certain criteria/assumptions for reliable results and inferences. Detailed discussion on preliminary steps/procedures of VAR estimates with specific test results and how to interpret the results are provided in the Appendix. ${ }^{14}$ In brief, the results from the group unit root test (e.g., Augmented Dickey-Fuller Test) indicated that variables used in this study do not have a unit root. Second, determining the lag length in VAR estimates is important because the result of the properties of VAR coefficients and estimations depends on the specified lag length of the VAR analysis. The author used fit statistics of the Log Likelihood Ratio (LR) to specify the lag length and the preliminary VAR estimates indicated that appropriate lag length is to be " 6 ," which is also plausible to absorb the impact of surrender on violence, or of incapacitation on surrender. Third, to reach robust VAR estimation, residuals should not be correlated over lagged time periods. To identify if serial correlations in residuals exist, the author ran the Serial Correlation LM Test and results indicated no serial correlation in the 12 lag orders. To verify the results for unit root/stationarity and autocorrelation, the author employed the stability test, which indicated that auto-regressive satisfies the stability condition and root lies outside the unit circle. In summary, all prerequisite tests were performed, and results indicated that the analysis met the assumptions for the VAR estimates conducted for this analysis.

\section{Findings/Results}

VAR estimates, in short, revealed that enactment of repentance did not have any significant impact on the PKK-initiated violence and on surrender of PKK fighters. Moreover, there is no meaningful relationship between PKK fighters' surrender and PKK violence. Finally, there is also no relationship between incapacitating PKK militants and their capitulation.

The VAR model examined the impact of repentance laws (REPENT) on PKK-initiated violence (VIOLENCE) and capitulated PKK fighters (SURRENDER). ${ }^{15}$ As plotted in Table 4, VAR results indicated that enactment of repentance laws (REPENT) did not have any significant impact on PKK initiated violence (VIOLENCE) when repentance (REPENT) was in effect. The obsolete value of $t$-score [ -0.08123 ] for VIOLENCE is way below the threshold value (1.96) for 0.05 confidence level. ${ }^{16}$ Likewise, granting a repentance opportunity to PKK members did not have any significant impact on PKK militants' surrender; as shown in Table 5, $t$-score [ -0.32354$]$ for SURRENDER is below the threshold value for the same confidence level. ${ }^{17}$

To analyze the relationships between surrendered PKK fighters (SURRENDER) and PKK violence (VIOLENCE), and between incapacitated PKK members (INCAPTER) and capitulated ones (SURRENDER), an impulse response function was plotted and secondly, to crosscheck the results, the Block Exogeneity Wald Test was used to examine the causal relationship among variables.

To identify any interrelated dynamics between SURRENDER and VIOLENCE and between INCAPTER and SURRENDER, the impulse response function is used. In the most generic sense, impulse responses trace out the response of current and future values of each of the variables in the system to a one-unit increase in the current value of one of the VAR errors by simply changing one error term while holding the others constant (when the errors are uncorrelated across equations in the system). ${ }^{18}$ 
Table 5. VAR results for the impact of RLs.

\begin{tabular}{lcrr}
\hline & INCAPTER & VIOLENCE & SURRENDER \\
\hline INCAPTER(-1) & 0.390375 & -0.011743 & 0.020322 \\
& $(0.07746)$ & $(0.04278)$ & $(0.05872)$ \\
INCAPTER(-6) & {$[5.03967]$} & {$[-0.27449]$} & {$[0.34607]$} \\
& -0.092863 & -0.163949 & -0.010346 \\
VIOLENCE(-1) & $(0.07610)$ & $(0.04203)$ & $(0.05769)$ \\
& {$[-1.22021]$} & {$[-3.90051]$} & {$[-0.17933]$} \\
VIOLENCE(-6) & 0.386018 & 0.169112 & 0.019674 \\
& $(0.13400)$ & $(0.07401)$ & $(0.10158)$ \\
SURRENDER(-1) & {$[2.88081]$} & {$[2.28507]$} & {$[0.19368]$} \\
& 0.108444 & 0.098920 & -0.021485 \\
SURRENDER(-6) & $(0.12535)$ & $(0.06923)$ & $(0.09503)$ \\
& {$[0.86510]$} & {$[1.42878]$} & {$[-0.22609]$} \\
& 0.036826 & 0.049962 & 0.154730 \\
C & $(0.10207)$ & $(0.05637)$ & $(0.07737)$ \\
& {$[0.36080]$} & {$[0.88629]$} & {$[1.99977]$} \\
& 0.041073 & -0.001021 & -0.012298 \\
REPENT & $(0.10210)$ & $(0.05639)$ & $(0.07740)$ \\
& {$[0.40227]$} & {$[-0.01811]$} & {$[-0.15889]$} \\
CEASEFIRE & 21.59044 & 7.659911 & 8.879320 \\
& $(6.41233)$ & $(3.54158)$ & $(4.86100)$ \\
& {$[3.36702]$} & {$[2.16285]$} & {$[1.82665]$} \\
\hline & -3.532813 & -0.213683 & -1.168177 \\
& $(4.76287)$ & $(2.63057)$ & $(3.61059)$ \\
& {$[-0.74174]$} & {$[-0.08123]$} & {$[-0.32354]$} \\
& -11.12455 & -7.271050 & 2.310122 \\
& $(5.11585)$ & $(2.82552)$ & $(3.87817)$ \\
& {$[-2.17453]^{* *}$} & {$[-2.57335]^{* * *}$} & {$[0.59567]$} \\
\hline
\end{tabular}

${ }^{*} p<.10$.

${ }^{* *} p<.05$

${ }^{* * * *} p<.005$

Standard errors in ( ) \& t-statistics in [ ]

(Only first $(-1)$ and sixth (-6) lag results are plotted in the table)

For the analysis of the relationship between VIOLENCE and SURRENDER, the impulse response function shows the response of PKK violence (VIOLENCE) to a one standard deviation increase (i.e., impulse shock, innovation) among the surrendered PKK militants (SURRENDER). As shown in Figure 2, despite that the trend line (solid line) for VIOLENCE indicates a slight increase in the first month in its interaction with SURRENDER it is not a statistically significant change, given the error bands (dashed lines) are not above the zero line. More technically, when one unit (a standard deviation) shock/innovation is given to the SURRENDER (over the error term), the VIOLENCE does not significantly change.

Likewise, an impulse response function is run for the relationship (interrelated dynamics) between incapacitation (INCAPTER) and surrendered (SURRENDER) PKK fighters. As shown in Figure 3, there is no statistically significant (meaningful) relationship between these two variables. That is, the trend line (solid line) for SURRENDER indicates a slight increase in the initial four months in its interaction with INCAPTER; however, this relationship is not statistically significant given the error bands (dashed lines) are not above the zero line.

To examine the causal relationships between variables INCAPTER, VIOLENCE, and SURRENDER, the Block Exogeneity Wald Test is run and results are delineated in Table 6. 


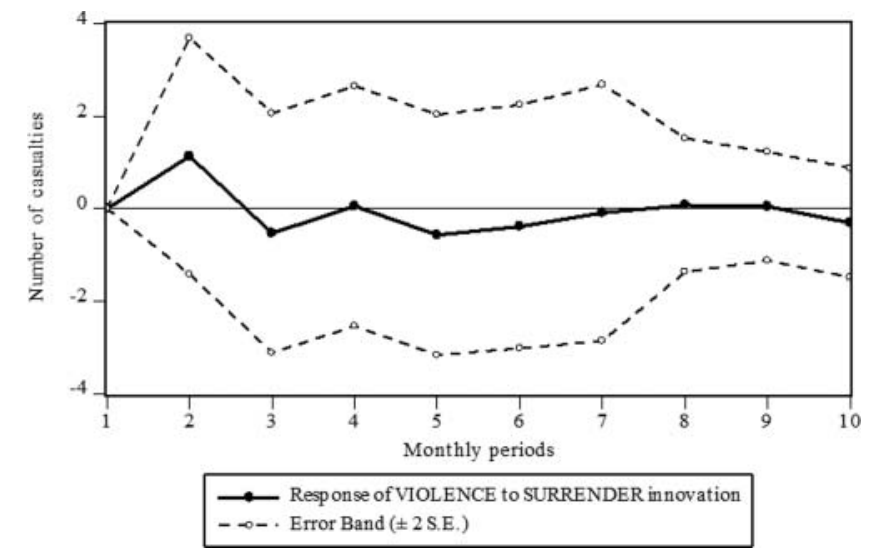

Figure 2. Response of VIOLENCE to Cholesky One S.D. SURRENDER Innovation.

As shown in the table, results converge with the results from impulse response function. There is no meaningful correlative relationship between SURRENDER and VIOLENCE given the $p$-value (0.9604). Likewise, no relationship is found between INCAPTER and SURRENDER given the $p$-value $(0.9372)$. These results indicated that there is only one causal relationship among these variables, it is between VIOLENCE and INCAPTER; $p$-value from VIOLENCE to INCAPTER is (0.387), and from INCAPTER to VIOLENCE, it is (0.0000), indicating a two-way endogeneity. In more technical terms, results show that the past values of VIOLENCE help predict INCAPTER at the 0.05 level, and, vice versa, at the 0.005 confidence level based on the Block Exogeneity Wald/Granger Causality Test. This can also be seen in the aggregate graphs of the impulse response function plotted in Figure 4; the impulse response function indicates (as seen in the second graph in the first row and the first graph in the second row) this statistically significant causal relationship between killing and injuring PKK fighters (INCAPACITATION) and casualties caused by PKK-initiated violent attacks.

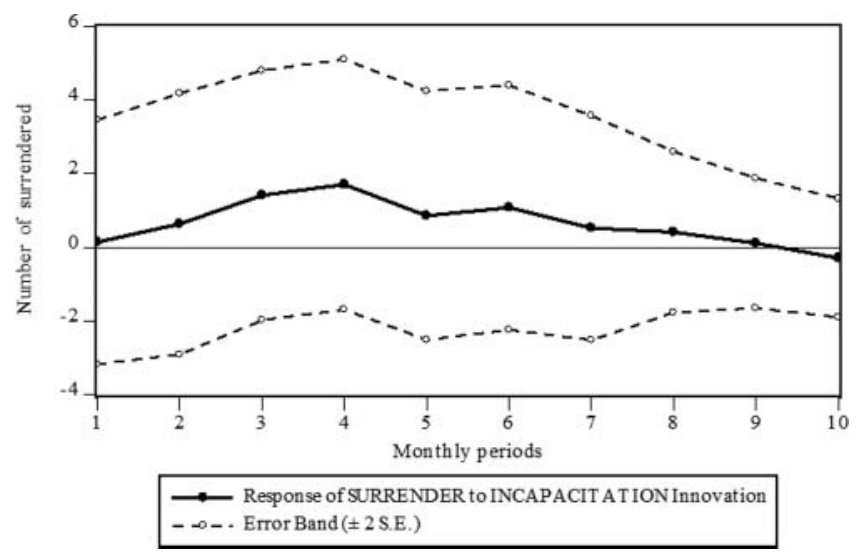

Figure 3. Response of SURRENDER to Cholesky One S.D. INCAPTER Innovation. 
Table 6. Pairwise granger causality/block exogeneity Wald test results.

\begin{tabular}{|c|c|c|c|}
\hline \multicolumn{4}{|c|}{ Dependent variable: INCAPTER } \\
\hline Excluded & Chi-sq & $\mathrm{df}$ & Prob. \\
\hline VIOLENCE & 13.28645 & 6 & $0.0387^{* *}$ \\
\hline SURRENDER & 0.788212 & 6 & 0.9924 \\
\hline & 13.83985 & 12 & 0.3111 \\
\hline \multicolumn{4}{|c|}{ Dependent variable: VIOLENCE } \\
\hline Excluded & Chi-sq & $\mathrm{df}$ & Prob. \\
\hline INCAPTER & 37.02060 & 6 & $0.0000^{* * *}$ \\
\hline SURRENDER & 1.486504 & 6 & 0.9604 \\
\hline & 38.25983 & 12 & $0.0001^{* * *}$ \\
\hline \multicolumn{4}{|c|}{ Dependent variable: SURRENDER } \\
\hline Excluded & Chi-sq & $\mathrm{df}$ & Prob. \\
\hline INCAPTER & 1.799493 & 6 & 0.9372 \\
\hline VIOLENCE & 0.269573 & 6 & 0.9996 \\
\hline All & 2.269517 & 12 & 0.9989 \\
\hline
\end{tabular}

What the overall results are of great importance. The variable VIOLENCE measuring casualty levels due to PKK-initiated attacks resulted in a significant decrease in the CEASEFIRE periods ( $t$-score [-2.57335]) as described in Table 5, indicating that the PKK mostly stuck to its unilateral cease-fires. So, constructed VAR Model indicates more reliable results by incorporating CEASEFIRE.

In summary, Figure 5 visually portrays the results for causal relationships among variables of INCAPTER, VIOLENCE, and SURRENDER. As shown in the diagram, there is no meaningful relationship neither between the number of surrendered PKK fighters (SURRENDER) and PKK-initiated violent attacks (VIOLENCE), nor between the number of incapacitated PKK fighters (INCAPTER) and surrendered/capitulated PKK militants (SURRENDER).

\section{Discussion}

Quantitative analysis found that there was no statistically significant association between the adoption of repentance laws and the level of PKK-initiated violence between 1995 and 2010. In other words, repentance opportunities neither had any significant and meaningful impact on the number of violent attacks conducted by the PKK, nor did they increase the number of surrendered PKK militants, which would have led to a mass disintegration and consequent dissolution of the organization, as hoped by the policymakers. Yet, VAR estimates indicated no meaningful relationship between incapacitation and surrender; and similarly no correlation between surrender and PKK-initiated violence for the same period of time.

Given the ineffectiveness of the Turkish RLs in leading PKK members' disengagement (individual and collective) and thus deterring the PKK insurgency, this section elaborates on such failure by providing brief analyses on four interrelated discussions to identify the 

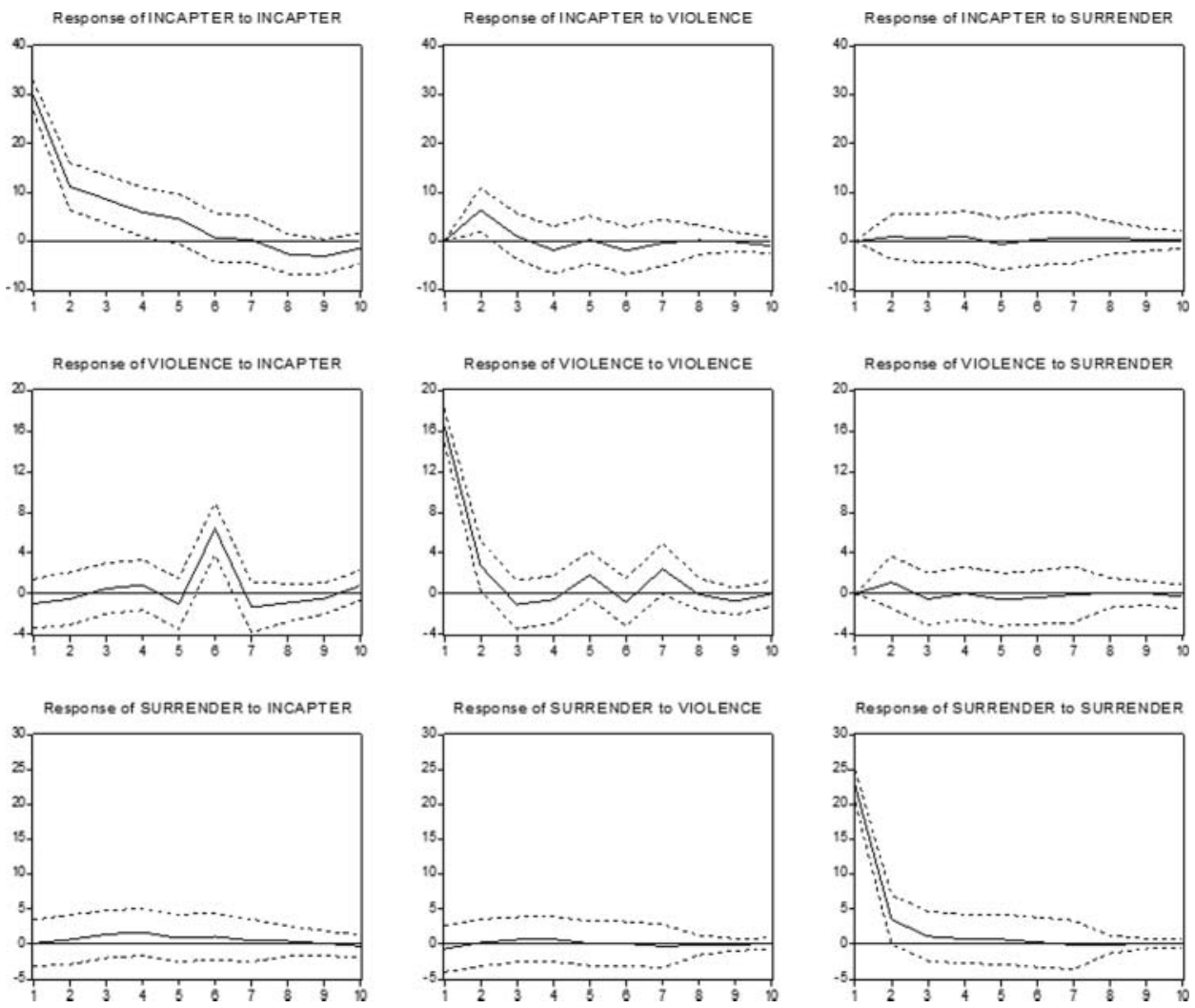

Figure 4. Response to Cholesky One S.D. Innovations \pm 2 S.E.

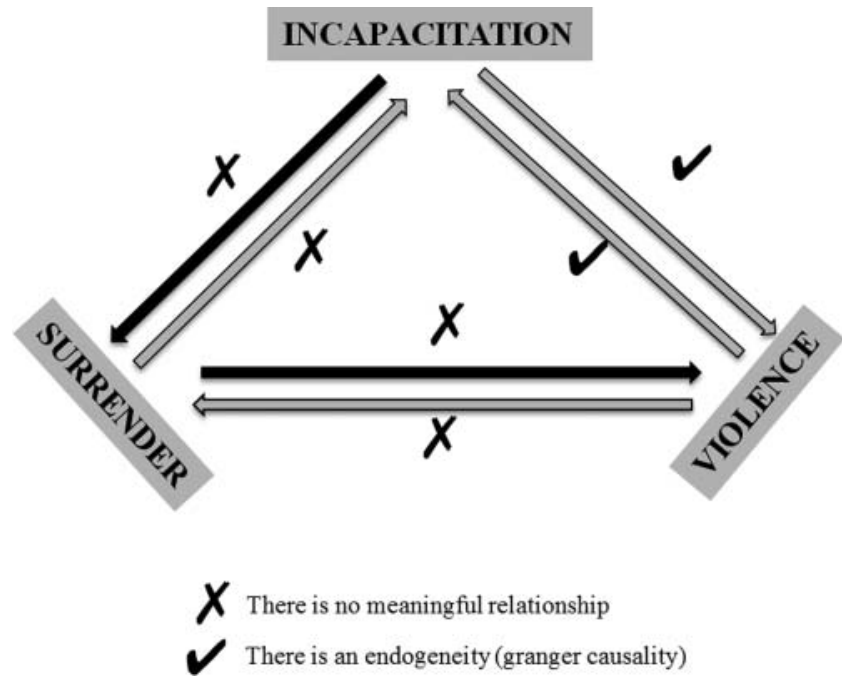

Figure 5. Results for the relationships among variables (INCAPTER, VIOLENCE, and SURRENDER). 
significant factors that led to such failure. Toward this end, this section first briefly reviews the theoretical grounding on individual and collective disengagement; second, it briefly discusses certain different cases from Spain, Italy, Colombia, Peru, and England; third, it analyzes the PKK and the process of conflict to identify and analyze the conditional dynamics and sociopolitical context that Turkish RLs were implemented; lastly, it briefly discusses the content and nature of Turkey's repentance laws.

\section{Theoretical Grounding}

First, and foremost, the abandonment of terrorism can be both individually and collectively ${ }^{19}$ with similar and differing dynamics. However, the underpinnings of repentance opportunities are related mostly to the individual disengagement from terrorist/insurgent violence, which has had less attention, as argued by John Horgan. ${ }^{20}$ Donatella Della Porta, on the other hand, asserted that disengagement studies leaned either on macro-level analysis (economic, social, and political characteristics) or on meso-level analysis (group dynamics) or on micro-level analysis (psychological characteristics) of individuals and argued that the analyses of critical interaction between these different analytical levels have been omitted for sociological interpretations. ${ }^{21}$ So, we know little particularly about the process and psychology to exit from violent extremist and terrorist groups and how different-level analytical frameworks interact and influence one another. What is certain, however, is that the various reasons behind why and how individuals disengage from terrorism, as Horgan argued, are vis à vis related to why and how individuals participate into and remain in a terrorist group. ${ }^{22}$ So, understanding why people individually surrender to then repent is as complex as identifying why individuals engage in terrorist activities.

According to Horgan, there exist two streams in individual disengagement; one being psychological (e.g., disillusionment) and the other being physical (e.g., role change). ${ }^{23}$ These two might be interrelated in a complex way (i.e., one leading or preceding other). Yet, both dimensions of disengagement might be voluntary or involuntary, in which the former indicates a personal decision by the individual while the individual is forced to exit in the latter. It is crucial to note, however, that leaving terrorism (involvement of violent action/activities) is different than disengagement in which-in the former-the individual might move in to a different role (not necessarily an illegal one) within the objectives of the terrorist movement. ${ }^{24}$

Physical disengagement includes arrest, imprisonment, death, and surrender. In that, while surrendering to security forces constitutes a voluntarily exit, there might be involuntary removal from the organization against the individual's will. ${ }^{25}$ In certain cases, terrorists are involuntarily physically removed from the organization (e.g., surrounded militants by security forces with no other chance to either surrender or capture or death). From a rational choice perspective, increased material cost with security applications, in particular with the military pressure (increased certainty of apprehension or increased risk of killed or injured) is a significant factor for involuntary physical disintegration. Such involuntary physical disengagements (e.g., arrest, capture, and imprisonment) mostly serve as a catalyst for the role change of terrorists within the same ideology and organization.

Psychological disengagement mostly occurs when there is perceived discrepancy between preliminary fantasy and the reality after involvement, which is called disillusionment. Disillusionment might also manifest itself in individuals' disagreement with an organization's 
politico-ideological, strategic, and tactical issues. ${ }^{26}$ Moreover, burnout and change in personal priorities lead the rise of disillusionment. Voluntary (e.g., security force operations and raids) disengagement as psychological process includes forcing and attracting factors (e.g., status, excitement, sense of unity, comradeship) that play significant roles in the person deciding to remain or to leave, ${ }^{27}$ which are beyond this study's scope. However, when and if earning trust, respect and place in the terrorist group is not overcome, the seeds for psychological disengagement in individuals start to prevail. ${ }^{28}$ Consequently, what makes individual disengagement complex and multifaceted is that all factors and reasons (i.e., physical, psychological, voluntary, and involuntary) can simultaneously be found in one individual's disengagement. ${ }^{29}$ More importantly, disengagement of an individual does not necessarily mean that individual's de-radicalization or repentance. ${ }^{30}$

In relation to granting repentance opportunities especially when the status quo (toward legitimate grievances) is maintained, and the conflict is intensified by sole security measures-as in the case of the PKK—individual disengagement mostly works for the utilitarian members of the group based on cost-benefit calculations as well as related disillusionment dynamics. In this regard, granting an opportunity via RLs in an ongoing conflict might result in disengaging/disintegrating from terrorist activity for those individuals who reconsidered their condition (gains/losses) and personally realized the discrepancy between their pre-participation aspirations/hopes and current difficulties, duties, and responsibilities that came with their new role as members of the organization.

Collective desistance/disengagement mostly works as a result of a dialogue and negotiations between the state authorities and violent organizations as part of negotiation and/or dialogue toward a demobilization, as was the case for the Euskadi Ta Askatasuna-politico militar (ETA-pm) in Spain and the United Self-Defense Groups of Colombia (AUC) in Columbia (elaborated later). Granting repentance opportunity is different from granting a general amnesty (for collective desistance), which mostly appears on the negotiation table in the context of a resolution process between warring parties. Otherwise, a collective desistance hardly comes in an ongoing fight, where states continuously employ harsh security measures and keep the status quo (root causes), which had led to violent oppositions.

In the aforementioned regard, the characteristics of government responses have a great impact on physical and psychological disintegration of individuals. Similar to the dynamics of external (popular) support, ingroup solidarity of insurgent/terrorist groups is self-maintained/ self-sustained when the group faces greater pressure from outside. This triggers the vital role that state countermeasures play. Repressive measures such as intense use of excessive military force (i.e., increased incapacitation), without a doubt, invoke counterproductive outcomes in this sense. This counterproductive impact not only manifests itself in increased terrorist attacks based on retaliatory sentiments but also tightens group bonds, ingroup solidarity, sense of unity, comradeship, and members of a violent group are led to strengthen their relationships with each other. Terrorist violence, in such an atmosphere, is perceptually legitimized and exit from the terrorist group is hardened, both psychologically (stigma of treason and social discredit) and physically (cautions taken by leadership and ingroup execution for signals to other potentially defecting members).

This is very much related to the core discussion in the literature about the "stick and carrot" method when countering terrorism. ${ }^{31}$ As known, the bulk of the debate revolves around such dichotomy; whether states should employ hard-line policies to punish terrorists by increasing material cost via deterrence policies, or they should adopt soft-line 
accommodative policies to focus on the motive/cause and reduce incentives to resort to terrorism (reward non-terrorist activity). ${ }^{32} \mathrm{Or}$, in addition to the nature, the timing-when to apply a specific policy-is another important matter in counterterrorism business. ${ }^{33}$ There is no easy answer to this question of course but what really, dramatically matters in responding to this question is very much related to the nature and specific characteristics of that particular case. In most cases, what is ignored is the careful identification of varying characteristics of a violent opposition and the dynamics of sociopolitical context at any particular period during the conflict process. These are crucially determinative for success or failure of state policies. Therefore, the nature, timing and characteristics of states' countermeasures have a dramatic impact not only on the group level dynamics but also on practices on the individual level, which is very much related to the success of granting repentance opportunities.

Another significant factor in violent conflicts is the motivation as the driving force in engaging in activities of political violence. As many argue, ${ }^{34}$ when it is an identity conflict related to ethnicity, it is more likely to last longer due to many reasons, one of which, and the most important one, is the sustained support (e.g., fresh recruitments, logistics, and intelligence) from a segment of the supporting population, deep-rooted culture of violence, resource mobilization via sympathizing population. In this context, state policies toward preventing individual integration and encouraging disintegration are critical issues to take into account when implementing countermeasures. As David Romano underlined, politicized ethnicity or ethnic identity-particularly the Kurds, given the historical background and Turkey's rigid stance against them - may reach a point that is beyond the rational choice explanations. ${ }^{35}$ In that individuals may no longer act as utilitarian. These people internalize new norms, values, and interests. The Kurdish issue in Turkey, after long years of failure addressing identity-related legitimate grievances, has become a taboo, and a new culture in which the ethnicity is highly politicized and agitated has been framed. Therefore, as Romano put, "[o]nce such a mentality is broken, it is impossible to go back to the way things were before," 36 and even the termination of the PKK in military sense would not lead to a peaceful cure and a sustained end of the issue. In this sense, to affect such politicized ethnic groups, the government should make the intervention on a mass scale to significantly impact the ethno-political struggles.

Therefore, understanding these characteristics and dynamics of the respective phases of the conflict is highly important to identify when and how to implement a specific policy. By the same token, the effectiveness of a repentance opportunity as a specific countermeasure highly depends on the context, timing, and the characteristics of the conflict as well as the state's overall perspective regarding countermeasures. This is largely because, as Horgan underlined, any policy designed for promoting individual disengagement critically requires a careful consideration of the social and political context that the parties (violent movement and the state authority) of the conflict evolve through at any particular moment in time. ${ }^{37}$

\section{Sample Cases}

Granting repentance opportunities has been a common counterterrorism tool resorted to by countries facing political violence. The Italian case is considered instructive in granting repentance as a countermeasure of terrorism. ${ }^{38}$ The Italian government, starting with the 
1980 antiterrorism law, adopted certain award measures (e.g., non-punishment, reduction in sentencing, and non-application of aggravating circumstances) for perpetrators' collaborative efforts with investigating authorities targeting penitents. It resulted in security forces' first consistent victories in their struggle against the terrorist groups, particularly the Red Brigades. ${ }^{39}$ Franco Ferracuti argued that the adoption of repentance opportunities (reduction of sentence as a pulling/attracting factor) in the Italian case resulted in tactical success when it was supplemented with strict security measures (pushing factors). In that context, terrorist acts conducted by the Red Brigade sharply declined from their peak of 2,513 in 1979 to just 30 in 1986, and numerous terrorists from the organization and from the prison submitted to the law. ${ }^{40}$ In addition to the Red Brigades, members of other armed groups in Italy also benefitted from these opportunities. Based on the official government figures, the law called "dissociazione" resulted in 389 beneficiaries (78 as "great repenters," 134 as "repenters" and 177 as "dissolvers"). ${ }^{41}$

However, it is not generalizable to all cases due to the different context: that is, conditional dynamics, evolutionary phases, nature, and characteristics of the conflict. The Spanish government also adopted a social insertion policy in 1982, which resulted in the ETA-pm's (politico military) disbandment while the Spanish government was in transition from dictatorship to democracy. However, as Regelio Alonso argued, this did not make a domino effect and has not let the ETA's disbandment despite the more democratic developments in the country. ${ }^{42}$ After the reinsertion and disbandment of the early 1980s, the ETA, in its later contacts with the Spanish government, acted more in a maximalist way based on a number of reasons, some of which include the killings of the GAL (Grupo Antiterrorista de Liberación) - a deep state extension group-de-legitimization of political reconciliation by the nationalists controlling ETA, and the government's continued negotiation offer that made a perception of the efficacy of terrorism and encouraged the continuation of violence. ${ }^{43}$ What led to ETA-pm's disbandment earlier in the process was not the nature of the repentance but rather the special dialogue between the ETA-pm and the government. ${ }^{44}$ Again, the key issue was the context in which neither party was willing to admit to or stipulate any political gain in exchange for disbandment. Therefore, ETA-pm's disbandment occurred based on different precipitating factors coupling in a social and political context, such as opening a democratic and political process, offering reinsertion opportunities, reconsidering the value and effectiveness of resorting to terrorism.

From a disengagement perspective, intense securitization with repressive countermeasures results in the organization becoming more closed and turning inward. ${ }^{45}$ Mechanization occurs in everyday life for its members. It is not only the war psychology that prevails. Additionally, only little room is left for the militants for other aspects of life both psychologically and physically. As Donatella Della Porta stated: “....[U]nderground organizations being totalitarian institutions that strongly limit the range of cognitive sources, consideration of the outside reality is normally filtered through a storyline that highlights the successes of the 'armed struggle."'46

Moreover, repression does not result in abandonment and if perceived to be too hard, it would bring a tightened bond and solidarity among group members, as was the case for the Red Army Fraction (RAF)'s success in its second wave of recruitment and prison activities in Germany. ${ }^{47}$ In the meantime, internal pressure increases and hierarchy-based interactions strengthen. In such a context criticizing values, rules, and simple applications of the organization, let alone questioning the organizational ideology, becomes a matter of treason and 
betrayal, which leads to internal executions within the organization. As in many other violent groups, internal executions and feuds have been very common within the PKK due to these reasons. Only in 2014, nearly 150 PKK militants were internally executed in their attempt to escape. ${ }^{48}$ In the ETA case, to name an example, numerous former membersmostly imprisoned ones-were killed by the ETA itself as a result of their statements to renounce violence. ${ }^{49}$ Likewise, 14 dead bodies belonging to members of the Japanese Red Army were found in 1969. They were then identified to have been tortured and killed by their fellow members due to their dispute over ideological issues. ${ }^{50}$ Therefore, violent groups harshly respond to award measures like repentance opportunities and subsequently execute their potential defectors and members who renounce the violent means. By so doing, leadership cadres aim to deter all members from defecting to overcome any potential development toward an organizational drift. In political violence (e.g., terrorism, insurgency) as a group process, psychological qualities of group membership induce strong potential not only for maintaining group solidarity but also for attracting new members. ${ }^{51}$ To increase and exploit such potential, terrorist/insurgent leaders enforce extreme conformity and strict obedience to the terrorist group's organizational values, in addition to inducing shared purpose or sense of unity for current and potential members. In such an organizational culture, one can reaffirm their identity as a group member by only engaging in risky violent activities that are considered central and valuable to the organization. In such a context, what PKK leaders did was creating this culture in which they enforced an implicit rule for new recruits to be involved in violent activities following their admission into the group to reduce the chance that they would accept a repentance opportunity, since the basic condition and eligibility criterion for early repentance laws consisted of non-involvement in violent activity.

Moreover, a conflict escalation favors ingroup solidarity within the organization, whereas long cease-fires periods cause the opposite. When the project of reaching the pre-designated political goal fails or its potential deteriorates, members start to be remorseful (psychological disintegration). As Della Porta argued “... [d] eparture from terrorism is linked to a perception of the inefficiency of the armed struggle." ${ }^{.2}$ Likewise, when a long cease-fire is declared for whatever reason (to recoup or as part of the resolution process), individual disintegration becomes easier. Factions tend to develop in such atmosphere and splinter groups might emerge with a negative perception of a change in the original project ${ }^{53}$ by questioning the nonviolent means and their reason to live on the mountains or underground.

Within the aforementioned respect, the PKK had also faced with potential factions particularly between 2000 and 2003, when the PKK declared its longest unilateral cease-fire following Ocalan's capture in 1999. In that period, the PKK strived to seek official representation of the Kurds in Turkey as a legitimate political entity by turning the PKK into the Kurdistan Freedom and Democracy Congress (KADEK) in 2002, ceasing violent acts, and into the Kurdistan People's Congress (KONGRA-GEL) in 2003 by rejecting violence altogether. However, the PKK failed and has, subsequently, been designated as a terrorist organization by a number of countries and international organizations. In this period, certain factions emerged within the PKK due to the long cease-fire and the failure in the international sphere (disillusionment and change of original project). Thus, certain splinter groups criticized the nonviolent means of KONGRA-GEL. To overcome any mass disintegration and to regroup the emerging factions around a sense of unity, the PKK escalated the violence by breaking off the cease-fire. Having no specific periodical objective for that period of time other than proving its power, the PKK conducted guerilla and terror attacks in a reactionary sense to 
maintain the ingroup solidarity and to regroup potential factions. ${ }^{54}$ To subdue those factions (with varying motives, e.g., creating a deviant leadership within the group), PKK also imposed internally executed operations to prevent the expansion of emerging factions. ${ }^{55}$ Similarly, a long process of many cease-fires between the Irish Republican Army (IRA) and the British government in order to continue the negotiations had caused serious unrest among the IRA members. IRA members perceived these peace negotiations as very slow, and believed that the IRA did not make significant progress with these political talks in $1975 .{ }^{56}$ Frustration, confusion, and demoralization emerged among the members. Later in the IRA conflict, the negotiations led to the "Good Friday" in 1998, but it also culminated in dissatisfied members forming the Real Irish Republican Army (RIRA), a marginalized splinter group relying on violent means to reach their goal. ${ }^{57}$

While physical and psychological individual dynamics (micro level) are determinant factors for individual disintegration, as underlined by certain scholars, such as Della Porta, Alonso, and Bjorgo and Horgan, the overall sociopolitical context (macro level) in which the conflict evolves through, the group level dynamics (and all of these levels interaction) have dramatic impacts on individuals' decision to disengage. Ferracuti also argued that the individual decision to abandon terrorism is related to reappraisal of self-interest and motivation $^{58}$ and such reappraisal becomes clearer in certain times when the founding leaders are killed or captured or a potential or actual failure of the terrorist/insurgent group. ${ }^{59}$ In those times, the psychological bond between the individual and the group weakens and so does the commitment. Individuals can no longer believe in the necessity of their engagement in such activity and justify their behavior in moral terms. ${ }^{60}$ In this respect, in certain phases and times during the conflict process, certain developments can play important roles on the results of repentance opportunities. These include, in addition to the capture of founding leader of the group, a catastrophic event influencing conflicting parties, a weighty operation by the state that resulted in a dramatic loss of terrorists/fighters, actions or inactions toward the grievances that determine the legitimacy of violence carried out by opposing groups (change in the perceptual legitimacy of terrorist violence), characteristics of dialogue, negotiations or any interaction for a resolution, if any, between warring parties.

Therefore, like most of other counterterrorism strategies, to what extent the repentance laws were effective is specific to that particular case due to the commonly accepted uniqueness of conditional dynamics in a conflict and its respective evolutionary phase. For instance, in addition to the ETA-pm's disbandment in Spain and the AUC's demobilization in Colombia, the Peruvian government's adoption of repentance portrays another relatively successful case that relates to its own context. The Peruvian government implemented a RL in 1992 to make members of the Shining Path (or Sendero Luminoso) surrender their weapons and provide information/intelligence in exchange for their progressive reinstatement into society. In total, an estimate of roughly 5,000 individuals applied to benefit from the law. ${ }^{61}$ Although it was argued that the majority of the applicants submitted to the law were composed of lower level supporters and sympathizers rather than real fighters and leaders, the law of 1992 was found effective to a certain degree. It came out in a conflict phase, when most leaders and founding members of the Shining Path were either captured or killed and the majority of its workforce was featured as landless urban unemployed men and women who lacked altruism and motivations that initial cadres had. Yet, it came out in a phase of the conflict during which the Shining Path began to lose power and momentum when founding leader Abimael Guzman was captured in September $1992 .{ }^{62}$ 
Moreover, after the ETA-pm's disbandment in Spain, reinsertion opportunities came out later in the process coincided with democratization (e.g., dismantling of military courts, certain decentralization/power share in public administration in Basque Region) period, which decreased the support for ETA violence. However, the effectiveness of reinsertion policies stayed at the individual level and certain number of members either active or imprisoned benefitted from these opportunities. ${ }^{63}$ To supplement the social reinsertion policy, the Spanish government implemented penitentiary policies to physically isolate the members of ETA from their homes in order to force them into defection, collaboration, and, eventually granting the possibility of not being charged with the crime and being able to be reintegrated into the society, under the condition that they confessed their crimes. The specific goal was to end the cohesiveness of the group and, for that purpose, political prisoners of pro-Basque and pro-ETA members were detained and kept in the same facilities of high security rural prisons. ${ }^{64}$ Alonso argued that social reinsertion measure did not deal with the organization as a whole but rather it was useful for individuals who already made up his/her mind for disengagement. Although not precipitating a mass disassociation, social insertion policy laid out a path to abandonment of terrorism in Spain. So, after ETA-pm's disbandment, the policy had a limited effect and only 370 individuals benefitted from the social insertion law until the mid-1990s. ${ }^{65}$

Similarly, the Colombian government used a number of demobilization policies. The aim was to facilitate individual and collective disintegration of members of the armed groups threatening Colombia and offering an opportunity for individuals to exit from the vicious circle of perpetual violence and to become reintegrated into the society. ${ }^{66}$ During Alvaro Uribe's presidential term, 31,000 AUC members collectively demobilized (along with 18,000 weapons) while approximately 11,000 insurgents from the Revolutionary Armed Forces of Colombia-People's Army (FARC-EP) and National Liberation Army (ELN) individually demobilized under the conditions of social award policies that date back to the 1990s. ${ }^{67}$ Despite large collective demobilization in Colombia, as Douglas Porch and María José Rasmussen argued, resulted with a collective desistence largely because incompatible environmental dynamics such as necessary policies and refinements of social reintegration, social and political dissent. Insurgents of armed groups were not terminated and transformed with appropriate programs and caution but rather they were transited to other violent means (related to narcotics business). ${ }^{68}$ So, despite the fact that demobilization attempts occurred to some extent, it was not a sustainable outcome toward the intended end. The demobilizations of the 1980s and early 1990s in Colombia failed to end the conflict due to lack of sociopolitical conditions that were required to sustain demobilizations and reinsertion of demobilized militants. As Marcella Ribetti asserted, for a durable disintegration in the context of Colombia that is dominated by a decade-long of culture of violence, three crucial issues should be simultaneously ready: sincere intention to abandon the violent group, former fighters' networks and environment, and, most importantly, a comprehensive program for demobilized insurgents for their gradual reinsertion into a new life without violence. ${ }^{69}$

\section{Process Analysis of the PKK}

As many prolonged insurgent fights, PKK conflict also evolved through different evolutionary phases. In these periods, internal and external dynamics of the organization reflected its 
changing character, which also had influences on, inter alia, group membership, participation, disintegration, and so on. In the PKK case, there have been five major phases that the conflict has undergone so far. In the first, PKK directly confronted security forces and challenged the legitimacy of the political authority using a Maoist "People's War" strategy between 1984 and 1993-94 that resulted in its military defeat. In the second phase, Ocalan recognized PKK's military and the PKK's shift to indirect challenge by employing revolutionary terrorism (attacking indirect targets such as civilians, public infrastructures in unrelated to its goal). ${ }^{70}$ In the third phase, once Ocalan was captured in 1999, PKK pursued a campaign aiming at a legitimate recognition in the international arena and ceased the violence between 2000 and mid-2003. In the fourth, from mid-2003 to 2007, the PKK revived the violent method to prove its threat level to Turkey's security and to maintain group solidarity. In the final and ongoing phase, PKK waged a political campaign with the creation of the Union of Kurdistan Communities $(\mathrm{KCK})^{71}$ to coerce Turkey into a political concession toward a negotiated settlement in which PKK employed strategic terror and guerilla attacks. Starting in 2009 Turkey was engaged in a resolution process, which broke off in 2011 and restarted in early 2013 and was crippled anew by July 2015.

To analyze the trends of individual disintegration among PKK fighters, Figure 6 plots the trend of surrender along with the state's use of force (incapacitation), and Figure 7 portrays the number of surrenders against the level of violence (number of violent incidents and casualties). In both figures, shaded areas indicate the first set of RLs, based on which Turkey employed an "Iron-Fist" approach defining military-led securitization as the major paradigm of counterterrorism/counterinsurgency. The vertical dashed line denotes the implementation of the RHB and the vertical solid line shows the adoption of the ERL. While the solid horizontal lines indicate the trend of surrender for both figures, dashed lines indicate the level of incapacitation for Figure 6 and the trend of violence for Figure 7. As seen in both figures, level of surrender shows more or less a parallel/similar trend either with the incapacitated PKK fighters (Figure 6) and with the overall violence trend (Figure 7) until Ocalan's Capture in 1999 (covering the confrontation phase of 1984-1994). This implies that when the context indicates direct fight (for territorial victory) there is no systematic difference for surrender other than the intensity of fight, which appears to be-from a rational choice perspective-surrender due to military pressure. As seen in the figures, however, this shows

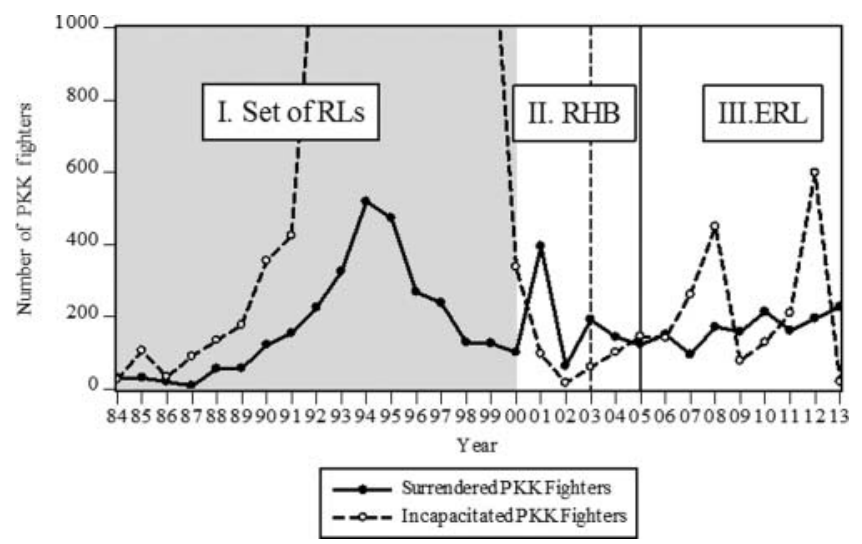

Figure 6. Number of surrendered and incapacitated (killed and injured) PKK fighters. 


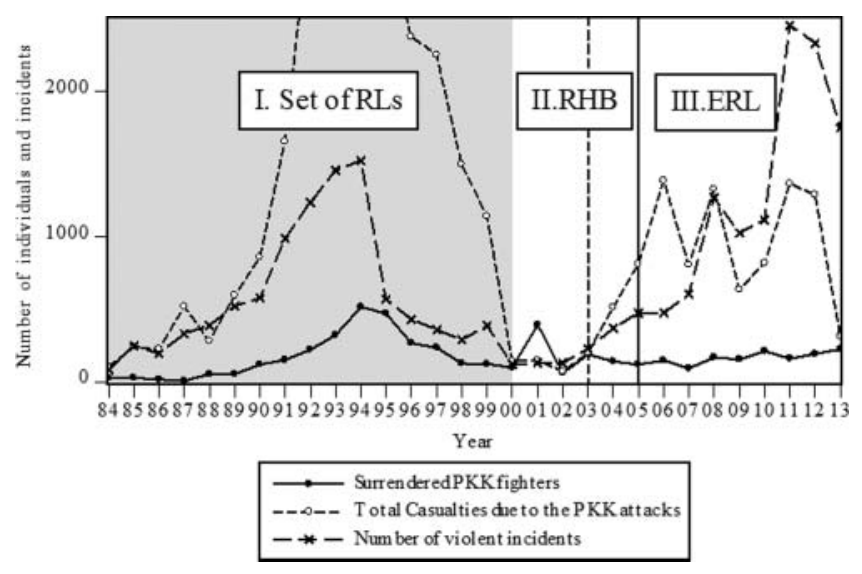

Figure 7. Number of surrendered PKK fighters and trend of violence (number of incidents and casualties).

a change after 2000s and indicates no parallel trend either with the level of violence or incapacitation. It should be noted that the VAR results indicating no meaningful relationship between incapacitation and surrender covers the period between 1995 and 2010 (due to data availability) and do not include the confrontation phase. So, descriptive analysis concurs with the VAR results that no meaningful relationship between use of force (incapacitation) and surrender exists for the period after 1995.

As shown in Figure 6 and Figure 7, the numbers of surrendered militants show two spikes; one in 2001 and the other in 2003. This can be seen more clearly in Figure 8, where the residuals for incapacitated and surrendered PKK militants and conflict violence are plotted. The highest residuals for surrender are in different years (in 2001 and 2003) than those of violence and incapacitation in the conflict process. As previously mentioned, violent organizations might be more prone to individual disintegration when their well-known founding leaders are either killed or captured. As it happened in the case of the Shining Path, nearly 400 PKK militants capitulated after 2001, following Ocalan's capture in 1999 and his call for withdrawal of the PKK from Turkish territories in 2000 .

Figure 9, on the other hand, depicts the capture (involuntary physical disintegration) of PKK members against the surrendered (voluntary disintegration) ones. As seen in the figure, the year 1993-94, which was marked as the PKK's military defeat, ${ }^{72}$ shows a dramatic decrease for the captured PKK members, while the trend for surrender is parallel with the overall violence and reaches its peak in 1994. So, in addition to the military pressure, the contextual influence of the perception of project failure (military defeat), as argued by Horgan, might have added in the sustained increase of surrender. Other than this, the spikes in surrender of 2001 and 2003 against the trend of capture are also noticeable in this figure; particularly in 2003, while capture goes down surrender indicates a an increase. After 2007 when Turkey initiated a peace/resolution process, surrender shows a volatile and slightly increasing trend in the central tendency while the level of captures shows a decreasing trend except in 2011. This is because the resolution process was broken off in 2010 and 2011. This again concurs what was discussed in the theoretical grounding section that while security force operations intensified (increased captures) the surrender shows decrease, which might 
INCAPTER Residuals

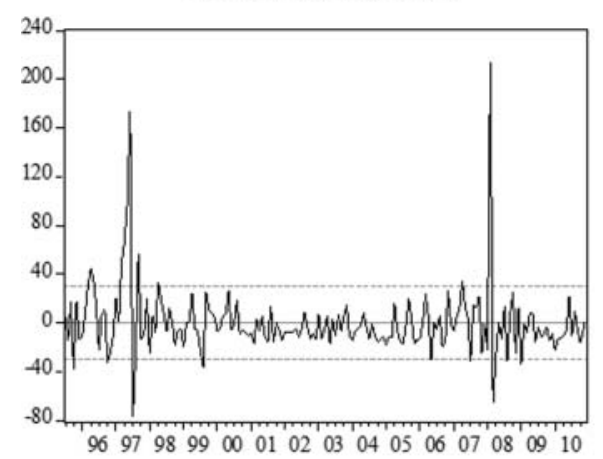

VIOLENCE Residuals

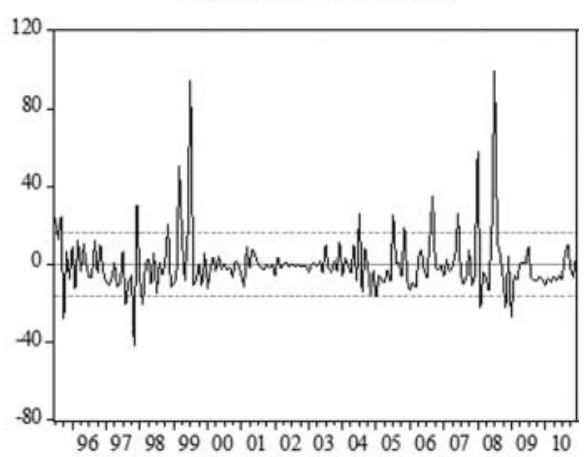

SURRENDER Residuals

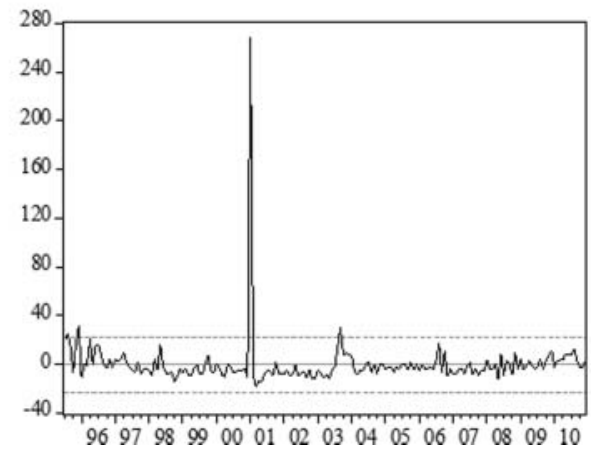

Figure 8. Residuals for PKK violence, incapacitated, and surrendered PKK militants.

be due to the hardened exit paths from organization as well as tightened group solidarity under the impact of both, external pressure and solidarity dynamics of employing violence.

As shown in Figures 6 and 9, the second and relatively weaker spike (considering the incapacitation trend) came out in 2003, where the RHB was enacted and had been active for six months. The RHB was a well-marketed law with an influential rhetoric of "Return

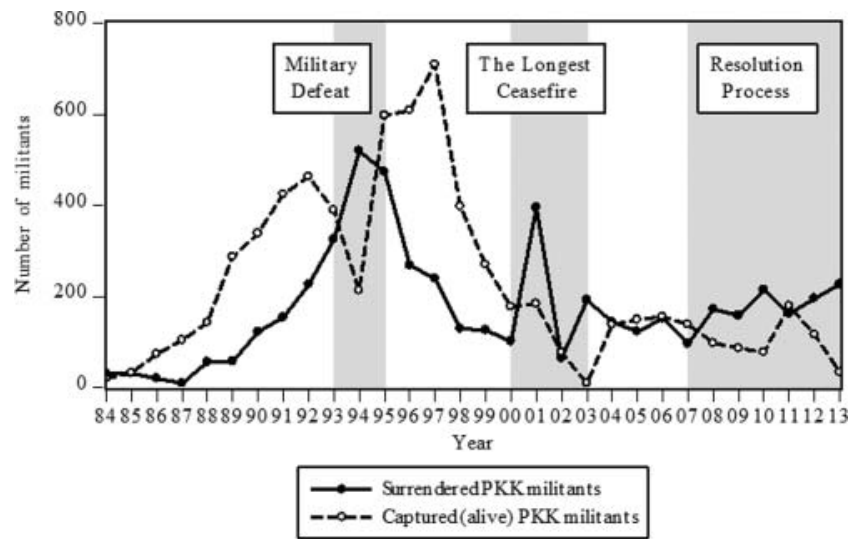

Figure 9. Trend of surrendered PKK fighters against the PKK militants who were captured (alive) by security forces. 
home" by the state. Despite its content-as analyzed later-the RHB attracted more PKK fighters to surrender with its content that facilitates witness protection and even certain employment opportunities for penitents to be reintegrated into the society. In addition to the trend of surrender, ${ }^{73}$ Figure 10 plots the number of applicants for each repentance law except the latest ERL. As shown in the figure, the highest number of PKK militants applied to the RHB compared to the earlier $\mathrm{RLs}^{74}{ }^{74}$ which constitutes the highest number of applicants.

These two spikes after the confrontation phase, one in surrender and the other in applicants, came out during a time when the PKK's leader had been captured and incarcerated, and PKK declared its long-lasting cease-fire. In the rest of the conflict, with the ERL being underway since 2005 , the trend of surrender appears to be slightly volatile and in an increasing general tendency, as seen in Figures 6, 7, and 9. As noted earlier, long cease-fires make individuals demotivated and remorseful, and reappraisal of the individual motive starts to prevail as well as questioning inflicted organizational conditions. The first two years of PKK's cease-fire might have played a significant role along with Oclalan's capture in these two spikes, one in 2001 and the other in 2003.

The official datasets retrieved form the government's database do not cover the period after the commencement of the peace process in 2013 and subsequent violence decrease. However, the media indicate that there has been a recent increase in the number of capitulated PKK fighters since the resolution process started. While these surrendered PKK fighters show great increase in recent period along with the resolution process, internally conducted executions also increased. Since March 2013 the number of surrendered PKK fighters reached $946 .{ }^{75}$ More importantly, most individuals who recently surrendered are relatively old and come from logistical support branches of the PKK. ${ }^{76}$ It is widely believed that this is also part of the PKK's strategy in that PKK exploits repentance opportunities to base its cadres into urban areas in a legal context. Otherwise it would be difficult for pro-PKK activities $^{77}$ to switch from rural strongholds to urban political structures. Horgan identifies this tactical issue, arguing disengagement might become apparent in cease-fire terms not for a real disintegration but for a role change as a result of decisions by the group's leadership. It is a tactical move to assign former front-line members to take on different kinds of activities within the boundaries of organizational aims. ${ }^{78}$ Supporting this argument, intelligence

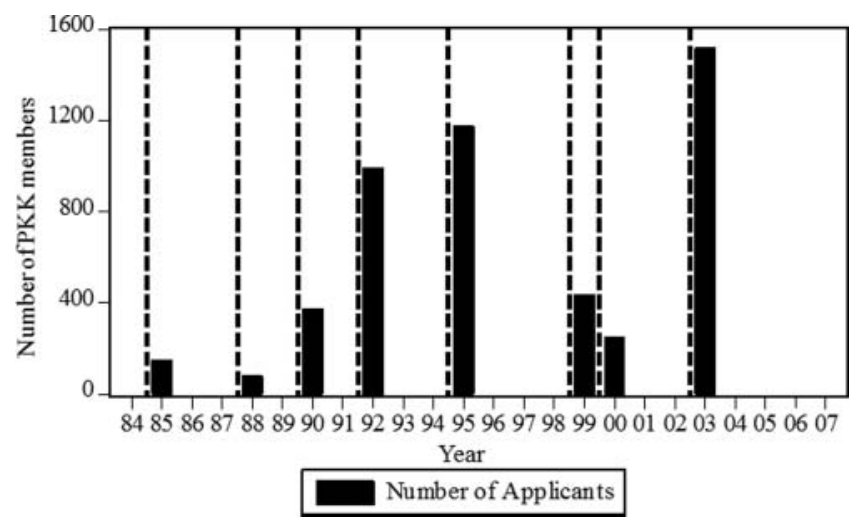

Figure 10. The number of applicants (PKK members) to the RLs. 
reports indicate an increase of the PKK membership ranks and its guerilla workforce. So, the State's use of repentance, as a countermeasure tool, is always subject to strategic and tactical moves by terrorist/insurgent groups, like in the case of the PKK to gain strategic advantage and to exploit State measures.

In addition to all, the author detected a pattern while analyzing the surrender trends. As shown in Figure 11, the highest average of surrendered occurred in January when the PKK militants settle underground (winter encampment) in order not to leave any traces on the snow, as not to be easily detected by the security forces. Surrenders mostly happened when the PKK was in the winter stationing. This signifies that wintertime is ideally suited for penitents to escape and surrender, avoiding being caught and executed by their PKK comrades.

\section{Content of Turkish Repentance Laws}

In addition to the dynamics of the overall context, the content, practice, and implementation of these laws also have a great impact on their results. What a repentance opportunity offers to individuals who opt to disengage is a crucial issue to discuss. In this sense, all three sets of RLs had different meanings and implications for potential penitents. First, the social identity that is offered by all RLs, except the latest ERL, was problematic. By stipulating a fully forced collaboration with security forces to be eligible for benefiting from repentance opportunity, the RLs and the RHB offered a social identity that considers penitents to be betrayers/traitors of their own nation, which is indefensible. As indicated in Table 2, the first two sets of RLs compelled any repentant to become a confessor (itirafçı), which drove extremely negative perceptions among the Kurds and the Kurdish media, as penitents are stigmatized with very derogatory/pejorative narratives in official and unofficial discourses, as Ozlem Biner elaborated. ${ }^{79}$ Only the ERL of 2005 laid out an opportunity for penitents to become a state witness (gizli tanık) without being compelled to denounce and incriminate his/her former comrades. ${ }^{80}$ Therefore, while the term "repentance" is used for the first two sets, the latest ERL did not use it as indicated in Table 2. These two different social identities incurred into significant psychological implications; even family members of the confessor reject and sometimes socially disown the penitent, given the pressure from the community they live in. Likewise, Italian repentance laws actually never mentioned the word "repentant" and only enlisted collaborative behavior in the legal text. However, the Italian media and public labeled it as "repentance."

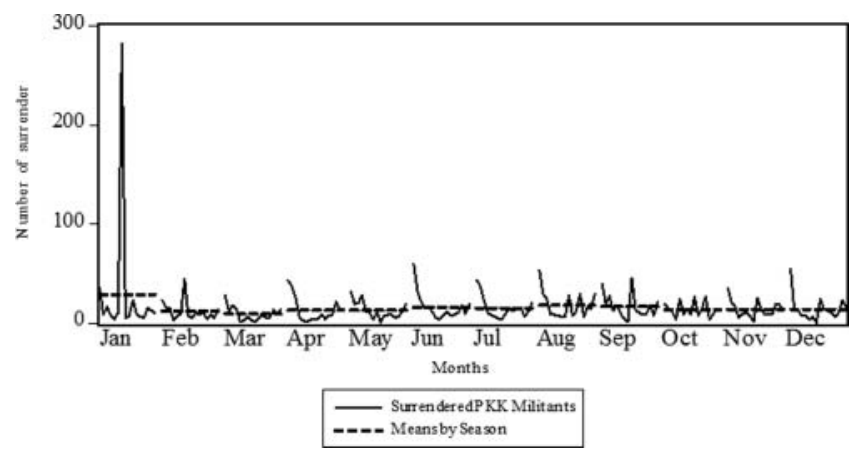

Figure 11. The average (mean) number of surrendered PKK fighters by season. 
Furthermore, what the initial seven RLs sought for was not actually opening a reinsertion door for penitents, but rather exploiting them in the state's security efforts. In that, penitents' obligation to collaborate with security forces is not consists only in providing information about the PKK members, their plans, and whereabouts but also, in certain cases, in partaking in security operations (mostly military operations) to help state forces to deprive PKK militants of their leaders. As Kamil Yilmaz mentioned, in certain cases, these confessors are even used by deep-state extensions (e.g., JITEM) in underground contra-guerilla operations to actually carry out violent attacks against the pro-PKK militia (similar to the GAL in the case of ETA). Put differently, the former sets of the RLs including the RHB forced applicants to continue their involvement in political violence in favor of the opposite side, which they once fought against, and to instead fight against individuals with whom they once worked. However, the new element introduced by the ERL is that beneficiaries of the ERL are now able to unequivocally separate themselves from violence and move into normalization, after the whole process of becoming a state witness. It is only the ERL that not only offered an amnesty or reduction in sentence based on certain conditions (similar to a juridical mechanism of "plea bargain"), but it also provided an opportunity and the necessary support for repenting individuals to be transformed and enter into a new way of life that is separated from terrorist activities. Similar to this, the repentance opportunity granted in the Italian antiterrorism law of 1980 had been tied to the level of collaboration and importance of information provided, such as identification of accomplices and incrimination of former comrades. However, in the Law of 1982, it was extended to those who wish to repent but not incriminate others, they could confess only about their own involvement in offences. Similar to the Turkish ERL, which lifted the psychological barrier of betraying one's own comrades. $^{82}$

Moreover, the exclusion of leaders and upper PKK cadres from the scope of the first two sets of repentance laws is also considered to be a hindrance to the policy's success. Because the PKK's organizational structure reflects a highly hierarchical nature, certain precautions taken by the leadership mechanism hampered the success of these laws. That is, according to the terms of the RLs, only PKK members who had not been involved in any form of armed conflict can be beneficiaries of the amnesty. Thus, as a strategic approach designed by the PKK leadership, new recruits were immediately involved in violent attacks on military targets to prevent them from benefits of the amnesty opportunity. This has changed with the ERL, according to which insurgent leaders would also be eligible to benefit from the law if they surrendered with the group under their lead. As Yilmaz asserted, while merely 1,800 individuals benefited from the first two sets of repentance laws in 18 years (from 1985, when the first RL was implemented, to the implementation of the latest RHB in 2003), the number of beneficiaries exceeded 1,200 in just seven years (between 2005 and 2012) after the ERL had been introduced. ${ }^{83}$ This signifies that the ERL came to be more successful both in terms of its requirements for applicants and the benefits it offered. The numbers that are broken down by terrorist organizations are not known in his data but it is certain-given the disproportionate domination of the PKK in terror activities occurred in Turkey-that the majority belongs to the PKK penitents. While the actual number of applicants who submitted to the ERL is not publicly shared (1,200 of beneficiaries mentioned in Yilmaz's study are those who submitted to the ERL and became state witnesses after passing all judicial procedures), the number of those who surrendered after the ERL is about 1,300 for the same period. Since incarcerated PKK militants can reap benefits from this law, what portion of the surrenders 
constitutes the aforementioned beneficiaries is not known. However, it is crucial to note that the total number of beneficiaries $(1,200)$ in seven years is so small to have significant impact on the PKK's insurgent activity when compared with the average annual workforce of the PKK that revolves around 5-6,000 after the mid-2000s. ${ }^{84}$ Likewise, the total number of applicants to the first set of RLs during the confrontation phase is so tiny to influence the overall conflict in favor of the government considering PKK's workforce varied between 11,000 and 13,$000 ;{ }^{85}$ in its peak time of the early 1990 s. $^{86}$ Such portion of individuals in an ongoing fight does not constitute an amount that significantly influences the PKK guerilla workforce, and thus it does not have a dramatic impact on the level of violent activities, as the results of both the quantitative and descriptive analyses suggest.

\section{Conclusion}

This study analyzed Turkish repentance laws and their intended impact on the Kurdish insurgency. Using the VAR analyses, this study found that, first, there is no meaningful/statistically significant relationship between granting repentance opportunities and the level of PKK-initiated violence for the 1995-2010 period. Second, adoption of repentance laws did not significantly increase the level of surrendered PKK fighters overall. Third, using intense coercive military force and practicing intense incapacitation did not lead PKK militants to surrender for the same period that would produce a mass disintegration and in the end a dissolution of the PKK, nor did it decrease PKK violence. In addition to the findings of the quantitative (VAR) analyses, the descriptive analysis identified that after the confrontation phase, the spikes in surrenders took place in 2001 and 2003, following Ocalan's capture in 1999, his subsequent call for withdrawal in 2000 and a long lasting cease-fire process. The RHB of 2003 and the ERL of 2005 have experienced an increased level of applicants compared with other repentance opportunities.

Analyzing the context and dynamics of the evolutionary phases and the content of the adopted RLs, this study asserts that there are numerous elements that lead to the success or the failure of repentance opportunities. First and the foremost, what is critically important is the social and political context in which the conflict evolves. When there is an ongoing fight and states' securitization and repression are underway, it is much easier for insurgent groups to maintain and sustain ingroup solidarity as well as acquiring active and passive (popular) support from their related people (tied with ethnicity, religion or any other identity related motive). Under such circumstances, what happens is the involuntary physical disintegration (e.g., capture, arrest, incapacitation) and voluntary disintegration (e.g., surrender of mostly egalitarian members due to military pressure). Therefore, the success of repentance policies becomes less likely. So, states' paradigm to curb the issue plays a particularly dramatic role for potentials of granting repentance opportunity. While the overall context of a conflict provides popular support to insurgents based on legitimate grievances in the social and political contexts, individual disintegrations (both voluntary and involuntary) of a very small portion of insurgents never have a significant impact in favor of the state in an ongoing struggle, as it happened in Turkey's struggle against the PKK.

What plays an important role in voluntary disintegration other than individual and organizational factors is the respective sociopolitical context in which the conflict evolves. The context has an immense influence on either individual or collective desistence. In that, different levels of macro, meso, and micro variables interact and play around one's individual 
decision or the group's collective tendency to hold up or to disengage. These, for instance, include reappraisal of individual conditions and motivations (micro level) along with individual perceptions of organizational values, goals/aims (actual feasibility of success) and ideology (meso level), legitimacy perception of incurred terrorist violence, government's respective overall approach and countering measures (macro level). ${ }^{87}$ In that, repentance opportunity is mostly a matter of voluntary psychological and physical disintegration for members of a violent group.

Another important factor is the harmony and conformity of implementing repentance opportunities with the state's overall strategy/approach. Most RLs in Turkey were implemented when harsh measures were imposed on the PKK and on the related population, which constituted a paradox. Hence, if a member of the PKK turns themselves in after spending years as an armed militant in the mountains, they would not have to serve any prison time based on all RLs. Contrary to this, however, they would get a five-year sentence due to their peaceful pro-PKK demonstration based on their link to the illegal PKK terrorist organization. This contradictory situation lasted until $2011 .^{88}$ Therefore, repentance opportunities should not only come at the right time, but also in the right context in which a cohesive and holistic approach should prevail in order to be effective and convincing for individuals. Whether repentance should be adopted along with tighter security measures for (increased material cost of death and injury) or along with soft-line policies for voluntary disintegration is a complex question. For cases of a long lasting protracted struggle like the PKK insurgency, both might be the case in different times and contexts as the conflict unfolded. In the PKK case, neither brought about a significant mass disintegration and a weighty impact on the overall conflict as found by this study.

Third, what is also a critical matter in granting repentance opportunities, in addition to the "when," is the "how (the content of the law)" the repentance law is formulated and implemented. Put differently, the social identity that the law offers and the conditions for penitents that the law stipulates to benefit from it have significant influence on the law's perception by individuals. In that, repentance opportunities should be designed not to help security forces but to open a real and clear window of opportunity for individuals to leave terrorism behind. Forcing penitents to sell out their former comrades conflicts with what the philosophical underpinnings of repentance opportunities contain. The state, as a responsible and legitimate authority for common good, should provide a way out from terrorism for those who wish to abandon terrorist activities and wish to return to their homes by completely disengaging from all violent activities. By doing so, the government must encourage dissents by opening a space for nonviolent political activity.

As final words, the effectiveness of a repentance opportunity as a specific countermeasure depends highly on the context, timing and the characteristics of the conflict as well as the state's overall countering perspective. This is due largely, as Horgan underlined, to the idea that any policy designed for promoting individual disengagement critically requires a careful consideration of the social and political context in which the conflict evolves through at any particular moment in time. ${ }^{89}$ This is because physical and psychological disengagement both voluntarily and involuntarily from politically motivated violent activities at an individual level is a multilevel (individual, organizational, societal) and multidimensional (interaction between these different levels) issue. Moreover, the content and the conduct of repentance laws as well as the context within which these reinsertion measures are implemented also 
critically matter. While repentance opportunity might be underway in most times, when it actually opens a functional door is highly related to the aforementioned dimensions. Nevertheless, while repentance opportunities might result in many defectors choosing to collaborate with state forces by turning themselves in (along with their weapons and valuable information on whereabouts and plans of their former fellow comrades), it is not a panacea to put an end to an ongoing protracted insurgent fight, where states keep the status quo and reject any sociopolitical reform and reconciliation. From this perspective, granting repentance opportunity as an award measure dramatically differs from negotiation-based collective desistance/disbandment. However, both should be supported with carefully designed social programs for penitents smooth transitioning from violence to a normal life.

As a result, Turkish repentance opportunities did not make a significant impact on the overall conflict due to the fact that Turkey's counterterrorism paradigm had long been a mere kinetically oriented approach in which repressive measures prevailed, not only in the physical security aspect, but also in the social and political arenas. Only after 2000 Turkey recognized and started to respond to legitimate grievances as the root cause of the Kurdish insurgency. Most repentance laws coincide with repressive measures in Turkey's iron fist paradigm and they were not effective enough to impact the overall Kurdish insurgency. The latest two laws came out when Turkey's accommodative policies were adopted, but they did not have a weighty impact on the overall conflict. This is mostly because Kurds have a politicized ethnicity that evolved over the years in light of the persistent conflict, which has led to the present cultural framing related to the deep-rooted ethnic identity. Given these tendencies, the government approach should be a long-term one going beyond the micro level counterterrorism approach and should operate on political, social and economic realms in order to address the underlying issues. Therefore, even if these RLs were effective to some degree, PKK insurrection would not have any difficulty finding new recruits, given the nature and characteristics of the overall struggle and related countermeasures/approaches adopted by Turkey.

\section{Notes}

1. David Romano, The Kurdish Nationalist Movement: Opportunity, Mobilization and Identity. (New York: Cambridge University Press, 2006).

2. David C. Rapoport, "The Four Waves of Modern Terrorism." In A. Kurth Cronin and J. M. Ludes, eds., Attacking Terrorism: Elements of a Grand Strategy (Washington, DC: Georgetown University Press, 2004), pp. 46-73.

3. Kai Ambos, Judith Large, and Marieke Wierda, Building a Future on Peace and Justice (Berlin and Heidelberg: Springer-Verlag, 2009).

4. Yonah Alexander, ed. Combating Terrorism: Strategies of Ten Countries (Ann Arbor, MI: University of Michigan Press, 2002).

5. "Terrorist" refer to individuals who engaged in activities defined as terrorist activity in the Law on Fight Against Terrorism of Turkey, Act Nr. 3713 "Article 1-Any criminal action conducted by one or more persons belonging to an organization with the aim of changing the attributes of the Republic as specified in the Constitution, the political, legal, social, secular or economic system, damaging the indivisible unity of the State with its territory and nation, jeopardizing the existence of the Turkish State and the Republic, enfeebling, destroying or seizing the State authority, eliminating basic rights and freedoms, damaging the internal and external security of the State, the public order or general health, is defined as terrorism." 
6. VAR analyses also provide us whether the PKK actually conformed to their unilaterally declared cease-fires.

7. Patrick T. Brandt and John T. Williams, Multiple Time Series Models Series: Quantitative Applications in the Social Sciences (Thousand Oaks, CA and London: Sage Publications, 2007); James H. Stock and Mark W. Watson, "Vector Autoregressions," Journal of Economic Perspectives (2001), pp. $101-115$.

8. Brandt and Williams, "Multiple Time Series Models" p. 9.

9. Ibid.

10. Stock and Watson, "Vector Auto-Regressions."

11. A reduced form of VAR model refers to that each variable as a linear function of its own past values and the past values of all other endogenous variables and serially uncorrelated error term.

12. Walter Enders and Todd Sandler, "The Effectiveness of Antiterrorism Policies: A Vector-Autoregression-Intervention Analysis," American Political Science Review 87(4) (1993), pp. 829-844.

13. Whether the PKK stuck to its unilateral cease-fires or not is also tested in the system statistically and PKK-initiated violence level for each individual cease-fire period is plotted with specific graphs to descriptively show the results.

14. The VAR system used in this analysis is a reduced form and it is built from a parsimony standpoint, reflecting a match with the available data, and they are also naive for the sake of brevity and simplicity in the interpretation of the results.

15. How to interpret VAR results is elaborated in the Appendix.

16. When $t$-statistics are used for hypothesis testing, the critical value of $t$-statistics for the confidence level 0.10 is $1.65\left(^{*}\right)$, for 0.05 confidence level it is 1.96 (denoted with ${ }^{* *}$ ), and for 0.005 confidence level it is $2.57\left({ }^{* * *}\right)$. These $t$-statistics/scores are based on the degree of freedom in which the sample size is more than 30 and for this analysis 180 observations are used, which is considered large enough to reflect a normally distributed sample.

17. In VAR analysis, results are read by the direction of the coefficient (not the magnitude) when results indicate statistically significant $t$-scores and $p$-values.

18. Stock and Watson, "Vector Auto-Regressions."

19. Donatella Della Porta, "Leaving Underground Organizations: A Sociological Analysis of the Italian Case." In J. Horgan and T. Bjorgo, eds., Leaving Terrorism Behind: Individual and Collective Disengagement (New York: Routledge, 2008), pp. 66-87.

20. John Horgan, "Individual Disengagement: A Psychological Analysis." In J. Horgan and T. Bjorgo, eds., Leaving Terrorism Behind: Individual and Collective Disengagement (New York: Routledge, 2008), p. 18.

21. Della Porta, "Leaving Underground Organizations," p. 67.

22. Horgan, The Psychology of Terrorism. p. 121.

23. Horgan, "Individual Disengagement," p. 20.

24. Ibid., p. 24.

25. Ibid., p. 25.

26. Horgan, The Psychology of Terrorism p. 122.

27. Clark R. McCauley and Mary E. Segal. "Social Psychology of Terrorist Groups," in Clyde Hendrick, ed., Group processes and intergroup relations. Review of personality and social psychology (Thousand Oaks, CA: Sage Publications, 1987).

28. Horgan, The Psychology of Terrorism.

29. Tore Bjorgo and John Horgan, eds., "Introduction," Leaving Terrorism Behind: Individual and Collective Disengagement (New York: Routledge, 2008), pp. 1-13.

30. Horgan, "Individual Disengagement."

31. Bruno S. Frey, Dealing with Terrorism: Stick or Carrot? (Cheltenham, UK: Edward Elgar Publishing, 2004).

32. Mustafa Cosar Unal, "The Dichotomy in the Perception, Conception and the Response to Terrorism: The Case of the PKK," Counter Terrorism in Diverse Communities 90 (2011), p. 268.

33. Diego Muro, "Counter-Terrorist Strategies in Western Europe: A Comparative Analysis of Germany, Italy, Spain and the UK” (San Domenico di Fiesole, Italy: European University Institute, 2010). 
34. Romano, The Kurdish Nationalist Movement, p. 16; Daniel Byman, "The Logic of Ethnic Terrorism," Studies in Conflict \& Terrorism 21(2) (1998), pp. 149-169; Nicholas Sambanis, "Do Ethnic and Non-Ethnic Civil Wars have the Same Causes? A Theoretical and Empirical Inquiry," Journal of Conflict Resolution 45(3) (2001), pp. 259-282; James D. Fearon and David D. Laitin, "Sons of the Soil, Migrants, and Civil War," World Development 39(2) (2011), pp. 199-211.

35. Romano, The Kurdish Nationalist Movement, pp. 16. 162-163.

36. Ibid, p. 160.

37. Horgan, "Individual Disengagement," p. 28.

38. Della Porta, "Leaving Underground Organizations."

39. Ibid.

40. As cited in Gregory D. Miller, "Confronting Terrorisms: Group Motivation and Successful State Policies," Terrorism and Political Violence 19(3) (2007), pp. 331-350; Thomas Gregor, ed. A Natural History of Peace (Nashville, TN: Vanderbilt University Press, 1996); Leonard Weinberg, The End of Terrorism? (New York: Routledge, 2013); Muro, "Counter-Terrorist Strategies in Western Europe."

41. Donatella Della Porta, "Institutional Responses to Terrorism: The Italian Case," Terrorism and Political Violence 4(4) (1992), p. 165; Della Porta, “Leaving Underground Organizations,” p. 70.

42. Rogelio Alonso, "Why Do Terrorists Stop? Analyzing Why ETA Members Abandon or Continue with Terrorism," Studies in Conflict \& Terrorism 34(9) (2011), pp. 696-716.

43. Ibid.

44. Ibid.

45. Horgan, The Psychology of Terrorism.

46. Della Porta, "Leaving Underground Organizations," p. 72.

47. Ibid., p. 69.

48. Aytekin Yilmaz, Yoldasini Oldurmek (Killing Your Comrade) (Istanbul, Turkey: Iletisim Yayinlari, 2014). Available at http://haber.star.com.tr/guncel/pkklidan-sok-itiraf-pkknin-infaz-ettigi-liderkadroyu-acikladi/haber-719201 (accessed 21 February 2015).

49. Please see Alonso, "Why Do Terrorists Stop?"

50. Ibid.

51. Horgan, The Psychology of Terrorism.

52. Della Porta, "Leaving Underground Organizations," p. 73.

53. Dilip K. Das, "Impact of Antiterrorist Measures on Democratic Law Enforcement: The Italian Experience," Studies in Conflict \& Terrorism 13(2) (1990), pp. 89-98.

54. Mustafa Cosar Unal, Counterterrorism in Turkey: Policy Choices and Policy Effects toward the Kurdistan Workers' Party (PKK) (New York: Routledge, 2012).

55. "Killing and Combout in the PKK." Available at http://www.nasname.com/a/pkkde-ic-hesaplasma-ve-derin-tasfiye- (accessed 16 May 2015).

56. Andrew Mumford, The Counter-Insurgency Myth: The British Experience of Irregular Warfare (New York: Routledge, 2012), pp. 94-124.

57. Ibid.; Horgan, The Psychology of Terrorism.

58. Franco Ferracuti, "Ideology and Repentance: Terrorism in Italy," in Walter Reich, ed., Origins of Terrorism: Psychologies, Ideologies, Theologies, States of Mind (Washington, DC: Woodrow Wilson Center Press, 1998), pp. 59-64.

59. Della Porta, "Leaving Underground Organizations."

60. As cited in Thomas Gregor, ed., A Natural History of Peace (Nashville, TN: Vanderbilt University Press, 1996).

61. James Forest, ed., Countering Terrorism and Insurgency in the 21st Century: International Perspectives. Vol. 3 (Santa Barbara, CA: Greenwood Publishing Group, 2007).

62. Ibid.

63. Alonso, "Why do Terrorists Stop?"

64. Jose Martinez Soria, "Country Report on Spain.” In C. Walter, S. Vöneky, V. Röben, and F. Schorkopf, eds., Terrorism as a Challenge for National and International Law: Security versus Liberty (New York: Springer, 2004), pp. 517-556.

65. Ibid. 
66. William, Rosenau, Ralph Espach, Román D. Ortiz, and Natalia Herrera, "Why They Join, Why They Fight, and Why They Leave: Learning From Colombia's Database of Demobilized Militants," Terrorism and Political Violence 26(2) (2014), pp. 277-285.

67. Douglas Porch and María José Rasmussen, "Demobilization of Paramilitaries in Colombia: Transformation or Transition?" Studies in Conflict \& Terrorism 31(6) (2008), pp. 520-540.

68. Ibid.

69. Marcella Ribetti, "Disengagement and Beyond: A Case Study of Demobilization in Colombia," in J. Horgan and T. Bjorgo, eds., Leaving Terrorism Behind: Individual and Collective Disengagement (New York: Routledge, 2008), pp. 152-169.

70. Mustafa Cosar Unal, "Strategist or Pragmatist: A Challenging Look at Ocalan's Retrospective Classification and Definition of PKK's Strategic Periods Between 1973 and 2012," Terrorism and Political Violence 26(3) (2014), pp. 419-448.

71. The KCK is an umbrella organization that was formed by the PKK to act as a quasi-state authority in economic, social, political/ideological, and self-defense realms in preparation for establishing situational/de facto autonomy in the region.

72. PKK's military defeat in territorial control only was implicitly acknowledged by Ocalan in a press conference in 1993 in northern Iraq and then in one of his statement to a pro-PKK periodical named Serxwebun, April 1994.

73. It is not known what portion of applicants are belong to surrendered PKK militants since there were many applications from the prisons among already incarcerated PKK members to reduce their sentencing.

74. Figure for the number of applicants to the ERL of 2005 is not known.

75. TRT News. Available at http://www.trthaber.com/haber/gundem/yilmaz-946-pkkli-teslim-oldu185111.html (accessed 12 May 2015).

76. Bugun Newspaper. Available at http://www.bugun.com.tr/gundem/pkkda-buyuk-infaz-haberi/ 1365990 (accessed 13 June 2015).

77. Ortadogu News. Available at http://www.ortadogugazetesi.net/makale.php?id=18195 (accessed 13 June 2015); Haberler news blog. Available at http://www.haberler.com/pkk-ydg-h-yi-polis-gucuolarak-kullaniyor-6831297-haberi/ (accessed 13 June 2015).

78. Horgan, "Individual Disengagement."

79. Zerrin Özlem Biner, "From Terrorist to Repentant: Who is the Victim?" History and Anthropology 17(4) (2006), pp. 339-353.

80. Kamil Yilmaz, "Politics of Repentance and the Role of Repentance Laws on Individual Disengagement from Political Violence in Turkey," International Political Anthropology 5(1) (2012), pp. $67-94$.

81. Franco Ferracuti, "Repentant Terrorist Legislation-A Preliminary Analysis of Problems and Results in Italy (From Outthinking the Terrorist-An International Challenge-Proceedings, P 57-61, 1985-See NCJ-98704)" (1985).

82. Ibid.

83. Ibid.

84. Haber7.com, "Kac PKK'li var." Available at http://www.haber7.com/guncel/haber/776398-toplam-kac-bin-pkkli-var-abd-acikladi (accessed 22 January 2015).

85. Unal, Counterterrorism in Turkey.

86. It is mentioned even as 15,000 in Aliza Marcus, Blood and Belief: The PKK and the Kurdish Fight for Independence (New York: NYU Press, 2007).

87. Della Porta, "Leaving Underground Organizations," p. 70.

88. Human Rights Watch Report no: 1-56432-708-6, "Protesting as a Terrorist Offense" (2009). Available at http://www.hrw.org/sites/default/files/reports/turkey1110webwcover.pdf (accessed 26 July 2015).

89. Horgan, "Individual Disengagement," p. 28.

90. J. T. McClave and F. H. Dietrich, II 1988 Statistics (San Francisco, CA: Dellen Publishing Company, 1988).

91. Brandt and Williams, "Multiple Time Series Models."

92. If a series is not stationary, it does not converge normal distribution at the convergence rate of. So, we cannot use the critical $T$-statistics produced for normal distribution. 
93. James Douglas Hamilton, Time Series Analysis. Vol. 2 (Princeton, NJ: Princeton University Press, 1994); Brandt and Williams, "Multiple Time Series Models"; Stock and Watson, "Vector AutoRegressions."

94. Ibid.

95. Hamilton, Time Series Analysis, p. 307.

96. Specification of lag length for all preliminary tests is based on default selection by the system itself. For the actual VAR analysis, specific test is run to determine the lag length for the entire VAR systems.

97. Brandt and Williams, "Multiple Time Series Models," p. 62.

98. Ibid.

99. Brandt and Williams, "Multiple Time Series Models."

100. Ibid., p. 65.

101. The magnitude of this exogenous variable (policy shift) sensitively depends on the dynamics of the whole system.

102. Brandt and Williams, "Multiple Time Series Models"; Hamilton, Time Series Analysis; Stock and Watson, "Vector Auto-Regressions."

103. Ibid.

104. Impulse response function assumes that the error (that belongs to one of the variables in the system and increased at one unit to get the response function) returns to zero in subsequent periods (fades out) and all other errors are equal to zero.

105. Brandt and Williams, "Multiple Time Series Models"; Stock and Watson, "Vector AutoRegressions.”

\section{Appendix}

\section{Procedure of VAR Analysis}

VAR estimates need to have certain criteria to meet so the results are reliable. These include, first, each series (time series variables) must be stationary, and in other words, variables should not have a unit root. Second, the appropriate lag length has to be specified based on certain criterion and fit statistics (e.g., Log-likelihood Ratio). Third, there should not be any serial correlation among the residuals and white noise disturbances and the VAR system should meet the stability criteria based on specific tests. In order to meet these criteria, I conducted related tests for each of these items for the entire set of VAR analyses since the results of these tests apply to all of the VAR estimates in this study. In this regard, VAR estimates are conducted by the following procedure:

- Running the unit root test to analyze the stationarity/non-stationarity for all series used in both VAR models,

- Granger Causality Block Exogeneity Test (pairwise, for all of the possible pairs),

- Preliminary VAR estimates,

- Determining the lag length,

- Running VAR estimates,

- Specification tests (residual test for serial correlation),

- Interpretation of VAR Results ( $t$-scores and impulse response function).

When $t$-statistics are used for hypothesis testing, the critical value of $t$-statistics for the confidence level 0.10 is 1.65 (denoted with ${ }^{*}$ ), for 0.05 confidence level it is 1.96 (denoted with $^{* *}$ ), and for 0.005 confidence level it is 2.57 (denoted with ${ }^{* *}$ ). These $t$-statistics/scores are based on the degree of freedom in which the sample size is more than 30 and considered large enough to reflect a normally distributed sample. ${ }^{90}$ 


\section{Unit Root Test-Stationarity}

Testing for unit root behavior (non-stationarity) of each endogenous series (variable) in the VAR system is important, because existence of unit root strongly indicates that there is a correction mechanism and thus the test for Granger Causality is biased. ${ }^{91}$ The results indicated that variables used in this study do not have unit root. Results are presented in Table A1 by testing the null hypothesis (H0): "Variable X has a unit root." Group unit root test results indicated no unit root (stationarity) problem based on $p$-values. That is, we can reject the null hypotheses: "variables have unit root" at the 0.01 level for all related variables (the produced $t$-scores are higher than critical $t$-values of $1 \%) .{ }^{92}$

\section{Granger Causality (GCT)/Block Exogeneity Test}

The GCT, suggested by Granger in 1969, addresses the question of how one variable can forecast the other, implying a meaningful endogenous relationship between the two time series variables. ${ }^{93}$ If Variable X does not Granger cause (a change in) the Variable $\mathrm{Y}$, then we can say that there is no meaningful relationship between Variable X and Y. In other words, Variable $\mathrm{Y}$ is not informative about the future values of the Variable $\mathrm{X}$ : "if an event $\mathrm{Y}$ is the cause of another event X then the event Y should precede the event X." "W4 While this premise can be true, there is criticism that such a relationship does not imply causality. However, the existence of Granger Causality between two time series variables strongly indicates endogeneity, a meaningful relationship. Hamilton ${ }^{95}$ indicated that, in general, some time series variables are found to be predictors of each other and this does not mean that these series cause each other. Rather, they are very informative on each other's future values, especially in time series that reflect a forward-looking behavior. As part of this research, Block Exogeneity Test was run to address whether or not there is a meaningful relationship between the variables INCAPTER, SURRENDER, and VIOLENCE and results are portrayed in Table 5.

\section{Lag Length Specification}

Determining the lag length in VAR estimates is important because the result of the properties of VAR coefficients and estimations depends on the specified lag length of the VAR analysis. ${ }^{96}$ Lag length basically indicates the number of lags that the VAR system would refer to retrospective values of each endogenous variable and treats each lag as a different endogenous variable to capture the effects of previous values on the present values of the endogenous variables. For example, the first lag of an endogenous variable refers to the previous month's value of that particular variable, since the data are restructured to have monthly interval data points in this study.

For the VAR estimates in this study, I used fit statistics of LR to specify the lag length for the constructed VAR models. Information criteria simply describe the improvement in the log likelihood penalized for the additional lags. Adding additional lags is only about efficiency penalty but not bias penalty. Additional lags may be needed when there is a serial correlation among the residuals in a certain range of distributed lags. ${ }^{97}$

Test for the lag length criteria, from the preliminary VAR estimates for the constructed VAR Model is plotted in Table A2. As indicated in tables, the structural system of the VAR model selected the lag length as " 6 " (marked with asterisk in Table A2, LR column) based 
Table A1. Unit root test results for variables used in the VAR estimates.

\begin{tabular}{|c|c|c|c|c|}
\hline Method & Statistic & Prob. $^{* * *}$ & Cross-sections & Obs \\
\hline \multicolumn{5}{|c|}{ Null: Unit root (assumes common unit root process) } \\
\hline Levin, Lin \& Chu t* & -9.42495 & 0.0000 & 5 & 955 \\
\hline Breitung t-stat & -7.23597 & 0.0000 & 5 & 950 \\
\hline \multicolumn{5}{|c|}{ Null: Unit root (assumes individual unit root process) } \\
\hline $\begin{array}{l}\text { Im, Pesaran and Shin W- } \\
\text { stat }\end{array}$ & -15.8974 & 0.0000 & 5 & 955 \\
\hline ADF - Fisher Chi-square & 240.893 & 0.0000 & 5 & 955 \\
\hline PP - Fisher Chi-square & 247.017 & 0.0000 & 5 & 955 \\
\hline \multicolumn{5}{|c|}{ Null: No unit root (assumes common unit root process) } \\
\hline Hadri Z-stat & 4.92828 & 0.0000 & 5 & 960 \\
\hline
\end{tabular}

Sample: 1995M01 2010M12.

Series: INCAPTER, VIOLENCE, SURRENDER, REPENT, CEASEFIRE.

***Probabilities for Fisher tests are computed using an asympotic Chi-square distribution. All other tests assume asymptotic normality.

on the LR. It captures the impact of the RL and surrendered PKK fighters in the sixth-month range in the VAR system.

\section{Specification Test for Serial Correlation}

In order for the VAR estimation to be robust, residuals should be uncorrelated over lagged time periods. There are multiple ways to test for the existence of serial correlations of the residuals; however, all these proposed tests are asymptotically equivalent. ${ }^{98}$ I used the Serial Correlation LM Test and stability test to identify if there is e autocorrelation between the different lags of variables over the five months period. As indicated in the Table A3 the LM test results indicate no serial correlation. That is, results indicate that we cannot reject the null hypothesis (H0) of "there is no serial correlation." Second, the stability/specification test (Roots of Characteristic Polynomial) as plotted in the Table A4, the developed VAR model satisfies the stability condition.

\section{Interpretation of VAR Results}

As mentioned in previous paragraphs, VAR is designed to identify the interrelated dynamics among multiple time series variables to identify if there is any meaningful relationship(s). ${ }^{99}$ It is very typical of VAR not to present and analyze the coefficients. This is because the coefficients mean nothing individually, especially for the endogenous variables. Rather, individual coefficients identify and describe the dynamics of the variables and, in turn, the behavior of the whole system. The inferences have to include and consider all of the [endogenous variables'] coefficients in the system at all distributed lag lengths. ${ }^{100}$ However, only the coefficient of the cease-fire variables that is incorporated as [exogenous variable] permanent level dummy shift can be analyzed (in the main VAR Model-1). Coefficients of the exogenous variables are analyzed not on their magnitude ${ }^{101}$ but only on their direction if the results are statistically significant. ${ }^{102}$ This means for in this study that the magnitude of coefficients of endogenous variables in the VAR system were not analyzed, only the direction of the coefficients (rather than magnitude) for policy variable(s) (RLs in our case, REPENT) that is exogenously incorporated into the system are analyzed to see if that policy intervention had any significant increasing or decreasing impact on the violence level. VAR results for the 
Table A2. VAR model lag order selection results.

\begin{tabular}{lccc}
\hline Lag & LogL & LR & SC \\
\hline 0 & -2466.263 & NA & 27.66257 \\
1 & -2440.413 & 49.97735 & $27.63499^{*}$ \\
2 & -2437.118 & 6.259883 & 27.85803 \\
3 & -2435.621 & 2.794015 & 28.10105 \\
4 & -2434.362 & 2.307818 & 28.34671 \\
5 & -2419.305 & 27.10315 & 28.43905 \\
6 & -2407.624 & $20.63660^{*}$ & 28.56891 \\
7 & -2405.104 & 4.368314 & 28.80056 \\
8 & -2398.851 & 10.63006 & 28.99073 \\
9 & -2396.529 & 3.868859 & 29.22458 \\
10 & -2391.922 & 7.524874 & 29.43304 \\
11 & -2390.595 & 2.123402 & 29.67794 \\
12 & -2389.648 & 1.483664 & 29.92707 \\
\hline
\end{tabular}

Endogenous variables: INCAPTER VIOLENCE SURRENDER.

Exogenous variables: C REPENT CEASEFIRE.

Sample: 1995M01 2010M12.

*indicates lag order selected by the criterion.

LR: sequential modified LR test statistic (each test at $5 \%$ level).

SC: Schwarz information criterion.

endogenous variables are interpreted with alternative methods. One of these methods is the impulse response function for the structural interaction (that portray the interrelated dynamics among the variables are used to make inferences) between endogenous variables in the VAR system. ${ }^{103}$

In the most generic sense, impulse response traces out the response of current and future values of each of the variables in the system to a one-unit increase in the current value of one of the VAR errors. ${ }^{104}$ It is simply changing one error term while holding the others constant when the errors are uncorrelated across equations in the system. ${ }^{105}$ For instance, the impulse response function shows the response of number of surrender (SURRENDER) to a one standard deviation increase (i.e., impulse shock, "innovation") in the number of incapacitation (INCAPTER) (over the error term). For all the analyses, I used E-views 5.1, a multiple

Table A3. Serial correlation LM test results.

\begin{tabular}{lll}
\hline Lags & LM-Stat & Prob \\
\hline 1 & 5.947133 & 0.7452 \\
2 & 9.131592 & 0.4252 \\
3 & 12.64460 & 0.1794 \\
4 & 6.528711 & 0.6861 \\
5 & 19.04685 & 0.0248 \\
6 & 6.206780 & 0.7191 \\
7 & 4.602320 & 0.8675 \\
8 & 5.816925 & 0.7581 \\
9 & 3.454361 & 0.9435 \\
10 & 5.243388 & 0.8126 \\
11 & 0.248772 & 1.0000 \\
12 & 5.503615 & 0.7884 \\
\hline
\end{tabular}

VAR residual serial correlation LM tests. $\mathrm{H} 0$ : no serial correlation at lag order $h$. Sample: 1995M01 2010M12.

Probs from chi-square with $9 \mathrm{df}$. 
Table A4. Stability test results (roots of characteristic polynomial).

\begin{tabular}{lr}
\hline Root & Modulus \\
\hline $0.736578-0.314957 \mathrm{i}$ & 0.801090 \\
$0.736578+0.314957 \mathrm{i}$ & 0.801090 \\
$-0.781156+0.162745 \mathrm{i}$ & 0.797928 \\
$-0.781156-0.162745 \mathrm{i}$ & 0.797928 \\
$-0.392458+0.684298 \mathrm{i}$ & 0.788851 \\
$-0.392458-0.684298 \mathrm{i}$ & 0.788851 \\
$0.314962-0.666125 \mathrm{i}$ & 0.736834 \\
$0.314962+0.666125 \mathrm{i}$ & 0.736834 \\
$-0.040736-0.703803 \mathrm{i}$ & 0.704981 \\
$-0.040736+0.703803 \mathrm{i}$ & 0.704981 \\
0.682870 & 0.682870 \\
$0.515847+0.184916 \mathrm{i}$ & 0.547989 \\
$0.515847-0.184916 \mathrm{i}$ & 0.547989 \\
$0.077672+0.486004 \mathrm{i}$ & 0.492172 \\
$0.077672-0.486004 \mathrm{i}$ & 0.492172 \\
$-0.347860-0.250824 \mathrm{i}$ & 0.428858 \\
$-0.347860+0.250824 \mathrm{i}$ & 0.428858 \\
-0.134355 & 0.134355 \\
\hline
\end{tabular}

Endogenous variables: INCAPTER VIOLENCE SURRENDER.

Exogenous variables: C REPENT CEASEFIRE.

Lag specification: 16.

No root lies outside the unit circle.

VAR satisfies the stability condition.

time series analysis software package. Datasets are transferred into E-views and converted into work-files.

The mathematical representation of the constructed VAR Model is plotted in the following Table A5. As seen in the table, INCAPTER, SURRENDER, and VIOLENCE are incorporated into the system as endogenous variables to question their correlative relationship. REPENT and CEASEFIRE are incorporated into the model as exogenous dummy shift variables to identify their impact, if any, on the interactive series of INCAPTER, SURRENDER (voluntary physical disintegration), and VIOLENCE (PKK-initiated violent attacks).

Table A5. Mathematical representation of the constructed VAR Model.

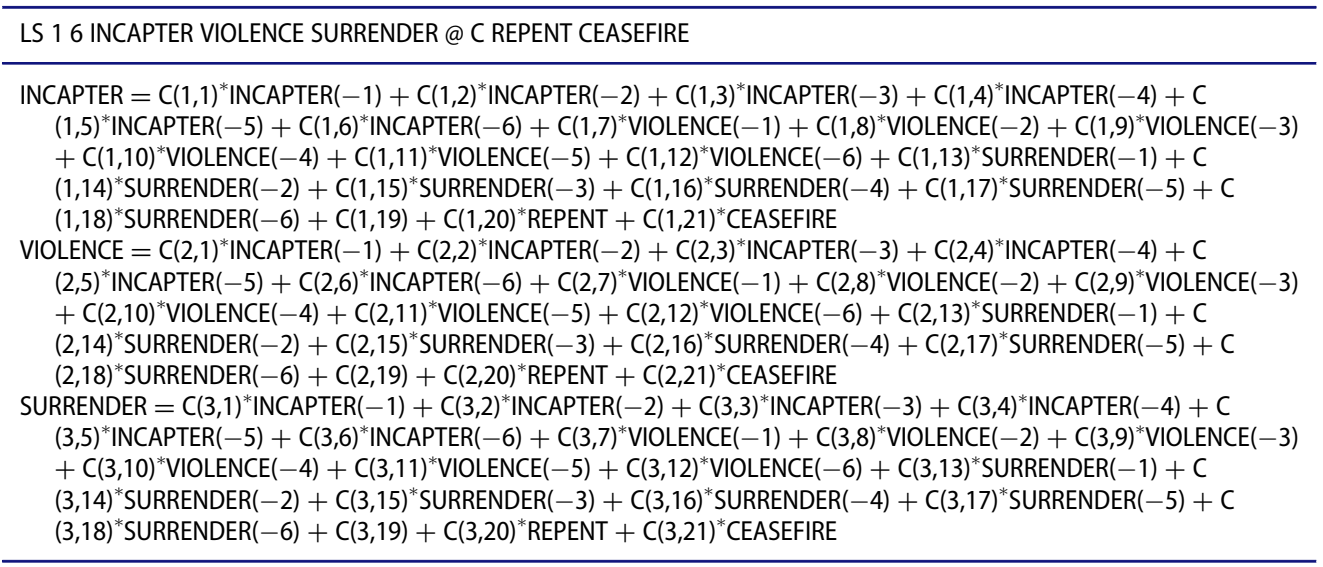

